\title{
Metallic Nanoscaffolds as Osteogenic Promoters: Advances, Challenges and Scope
}

\author{
Sougata Ghosh ${ }^{1, *(D)}$ and Thomas Jay Webster ${ }^{2}$ (D) \\ 1 Department of Microbiology, School of Science, RK University, Rajkot 360020, India \\ 2 Department of Chemical Engineering, Northeastern University, Boston, MA 02115, USA; \\ websterthomas02@gmail.com \\ * Correspondence: ghoshsibb@gmail.com
}

check for updates

Citation: Ghosh, S.; Webster, T.J. Metallic Nanoscaffolds as Osteogenic Promoters: Advances, Challenges and Scope. Metals 2021, 11, 1356. https://doi.org/10.3390/met11091356

Academic Editors: Leszek

Adam Dobrzanski, Jürgen Eckert and Norbert Hort

Received: 16 June 2021

Accepted: 26 August 2021

Published: 29 August 2021

Publisher's Note: MDPI stays neutral with regard to jurisdictional claims in published maps and institutional affiliations.

Copyright: (c) 2021 by the authors. Licensee MDPI, Basel, Switzerland. This article is an open access article distributed under the terms and conditions of the Creative Commons Attribution (CC BY) license (https:// creativecommons.org/licenses/by/ $4.0 /)$.

\begin{abstract}
Bone injuries and fractures are often associated with post-surgical failures, extended healing times, infection, a lack of return to a normal active lifestyle, and corrosion associated allergies. In this regard, this review presents a comprehensive report on advances in nanotechnology driven solutions for bone tissue engineering. The fabrication of metals such as copper, gold, platinum, palladium, silver, strontium, titanium, zinc oxide, and magnetic nanoparticles with tunable physico-chemical and opto-electronic properties for osteogenic scaffolds is discussed here in detail. Furthermore, the rational selection of a polymeric base such as chitosan, collagen, poly (L-lactide), hydroxyl-propyl-methyl cellulose, poly-lactic-co-glycolic acid, polyglucose-sorbitol-carboxymethy ether, polycaprolactone, natural rubber latex, and silk fibroin for scaffold preparation is also discussed. These advanced materials and fabrication strategies not only provide for appropriate mechanical strength but also render integrity, making them appealing for orthopedic applications. Further, such scaffolds can be functionalized with ligands or biomolecules such as hydroxyapatite, polypyrrole (PPy), magnesium, zinc dopants, and growth factors to stimulate osteogenic differentiation, mineralization, and neovascularization to aid in rapid healing. Future directions to co-incorporate bioceramics, biogenic nanoparticles, and fourth generation biomaterials to enhance biocompatibility, mechanical properties, and rapid recovery are also included in this review. Hence, the further development of such biomimetic metal-based nano-scaffolds at a lower cost with reduced risks and greater efficacy at regrowing bone can revolutionize the future of orthopedics.
\end{abstract}

Keywords: metal nanoparticles; implants; biopolymers; functionalized ligands; osteogenic differentiation; bone tissue engineering

\section{Introduction}

Recent advances in the field of bioengineering have employed nanotechnology to revolutionize conventional therapies which are often ineffective and fail to provide long term relief to patients [1]. The natural hierarchical structures of human tissues at the nanoscale emphasize the need to explore the "small" to fix the bigger problems. Hence, nanomaterials (ranging from 1 to $100 \mathrm{~nm}$ in size) are advantageous as they can mimic the tissue nanoenvironment and significantly modulate biological responses [2]. Nanostructured vehicles have been reported as efficient drug delivery systems that can traverse biological barriers, such as the small intestine, nasal and oral mucosa pathways, and the skin [3]. Additionally, the larger surface area to volume ratios of nanoparticles can be multifunctionalized with drugs, growth factors, targeting ligands, contrast agents, and other bioactive agents to make multifunctional materials [4,5]. Such nanocomposites which can accomplish both therapy and diagnosis are termed theranostic agents [6-8]. Such nanoparticles coupled with conjugating moieties, such as peptides, aptamers, and small molecules, help to deliver drugs specifically to the target tissue, thereby preventing adverse effects of non-specific drug accumulation and toxicity $[9,10]$. More recently, nanoparticles have been used for fabricating multifunctional scaffolds for tissue engineering applications [11-16]. 
Extensive research on the fabrication of advanced biomaterials with attractive surface properties, mechanical strength and durability has resulted in nanotechnology-based strategies to ameliorate bone related diseases [17-19]. Conventional clinical therapies often fail to cure skeletal-related disorders, such as osteoarthritis (OA), osteoporosis (OP), non-union bone defects, bone cancer, and myeloma-related bone diseases [20-23].

In the USA alone, approximately 52.5 million adults suffer from clinical OA while almost 10.2 million adults aged 50 years and older suffer from OP. 43.4 million adults have a high risk of developing OP due to low bone mass [21]. Certainly as well, even in those cases where clinical unions occur, after implantation, patients do not return to an active lifestyle [1,22]. Novel materials which can promote osteoblast (or bone forming cells) differentiation, proliferation, adhesion, and integration have received wide attention which may solve these persistent problems with conventional orthopedic implants $[24,25]$.

Biomaterials employing nanoengineering and nanofabrication technologies present promising biomimetic approaches as they resemble natural biological tissues with respect to structural, mechanical, and sometimes chemical properties. The adherence and growth of cells with desired functionalities can be controlled by the chemical nature, spatial geometry, porosity, and complexity of such 3D nano-scaffolds. Nanostructures with exotic shapes such as fibers, spheres, sheets, hollow tubes, and nets can be used for fabricating unique scaffolds for orthopedic tissue engineering including bone, cartilage, tendons, and ligaments [26]. Hard tissue engineering related to bone ideally requires nanomaterials with great mechanical strength, such as ceramic-based nanomaterials including hydroxyapatite, calcium phosphates, nanosilicates, and bioactive glasses. Nanoscale hydroxyapatite (HAp) has been extensively used as orthopedic implants for bone regeneration [27]. Similarly, carbon-based nanomaterials, such as carbon nanotubes (CNTs), graphene (G), and nanodiamonds (NDs), have also been incorporated in scaffolds due to their superior ability to induce osteogenic differentiation in stem cells [28,29].

However, metallic nanoparticles are preferred for bone implants due to their wellestablished presence in the field, durability, mechanical strength, and biocompatibility [30]. This review provides a comprehensive account of advances in the field of developing nanoscaffolds using metallic nanoparticles for bone tissue regeneration. Several nanoscale metals such as copper, gold, iron oxide, platinum, palladium, silver, strontium, titanium, zinc, and their oxides are discussed with respect to their promising role in bone tissue regeneration as listed in Table A1. Further, strategies for incorporating these nanoparticles within polymers such as poly (lactic-co-glycolic acid) (PLGA), poly (L-lactic acid) (PLLA), poly (caprolactone) (PCL), collagen, hyaluronic acid, silk, alginate, and fibrin to enhance mechanical properties, bioactive characteristics, and biocompatibility are presented. Critical comments on the future of such developments and additional modification ideas for nanoscaffolds to serve as biomimetic materials for drug delivery with better resorption and enhanced bone tissue healing properties are also included.

\section{Systematic Review of Literature}

Literature Search

A structured review of research articles was conducted in accordance with the methodology described by van den Bosch et al. (2017) [31]. An electronic literature search was conducted and finalized in June 2021, using the databases Scopus, PubMed, and Web of Science. The search was limited to peer-reviewed articles written in English. The results were filtered by study type to include both research articles and reviews. Additionally, both in vitro studies and in vivo studies were taken into account while assessing bone tissue regeneration efficiency.

No other filters were applied. Search terms were related to: (i) metal nanoparticles; (ii) scaffolds; and (iii) bone tissue regeneration and were combined and searched for in keywords, topic, title and abstract, or MeSH-terms (PubMed). In order to widen the search beyond the protocol, snowball sampling and scanning of the bibliographies of identified articles were carried out. Research on bone tissue regeneration using metallic 
nanoparticle-based scaffolds was the basis of the selection of search terms that relied on existing metabolic pathways [32].

Further, the titles and abstracts of articles, identified by the searches, were reviewed by the authors independently. Entire articles were selected for this review only if at least the retrieved abstract fulfilled the inclusion criteria which was based on the AMSTAR tool to ensure that only high-quality articles were included [33].

We applied the following inclusion criteria:

- Systematic reviews and research articles

- Including a quality evaluation of supportive experiments

- Published in a peer-reviewed, scientific journal

- Written in English

- Establishing the underlying mechanism of bioactivity

Articles not identifying the search terms used, not providing synthesis methods and characterization data of nanometals, and/or not describing proper control experiments were excluded. As the aim of this review was to highlight the potential of metal nanoparticles-based scaffolds mainly for bone tissue regeneration, we did not consider reviews on other ailments. We also excluded any reviews on polymeric scaffolds that did not have metallic nanoparticles. Equally, we excluded research articles on carbon based and ceramic based nanoparticles used for tissue engineering.

\section{Data Extraction}

Each and every article was scrutinized by the authors for strict fulfilment of inclusion criteria with the extraction sheet including data on the type of metal nanoparticle, size in nanometer (nm), type of matrix used for scaffold fabrication, and the type of in vitro and/or in vivo studies used in order to support the claim for bone tissue regeneration. A summary of the results from the extraction sheet is provided in Table A1. As our review considers one type of "intervention" (scaffolds), though of varying composition (based of diverse metallic nanostructures), and its effect on osteogenic induction, mineralization and tissue differentiation, we considered extracting the results from diverse types of metallic nanoparticles to highlight the heterogeneity in the type of nanoscaffold as a function of metals and matrix used [34].

\section{Results}

The initial search resulted in 286 retrievals. A first scan of titles and abstracts was carried out limiting the amount of potentially relevant papers to a total of 185 . The remaining potentially eligible full papers were reviewed and evaluated as fulfilling inclusion criteria or not, resulting in a final inclusion of 115 articles as illustrated in the flow chart in Scheme 1 . The research articles involving polymeric nano/micro structures, mesoporous non-metallic nanomaterials and bioceramics were not analyzed and were excluded from the review. Results were extracted for each respective article separately based on the type of metallic nanoparticle, their morphological features, nature of the polymeric matrix for impregnating the nanometals, and the in vitro and/or in vivo osteogenic activity. 


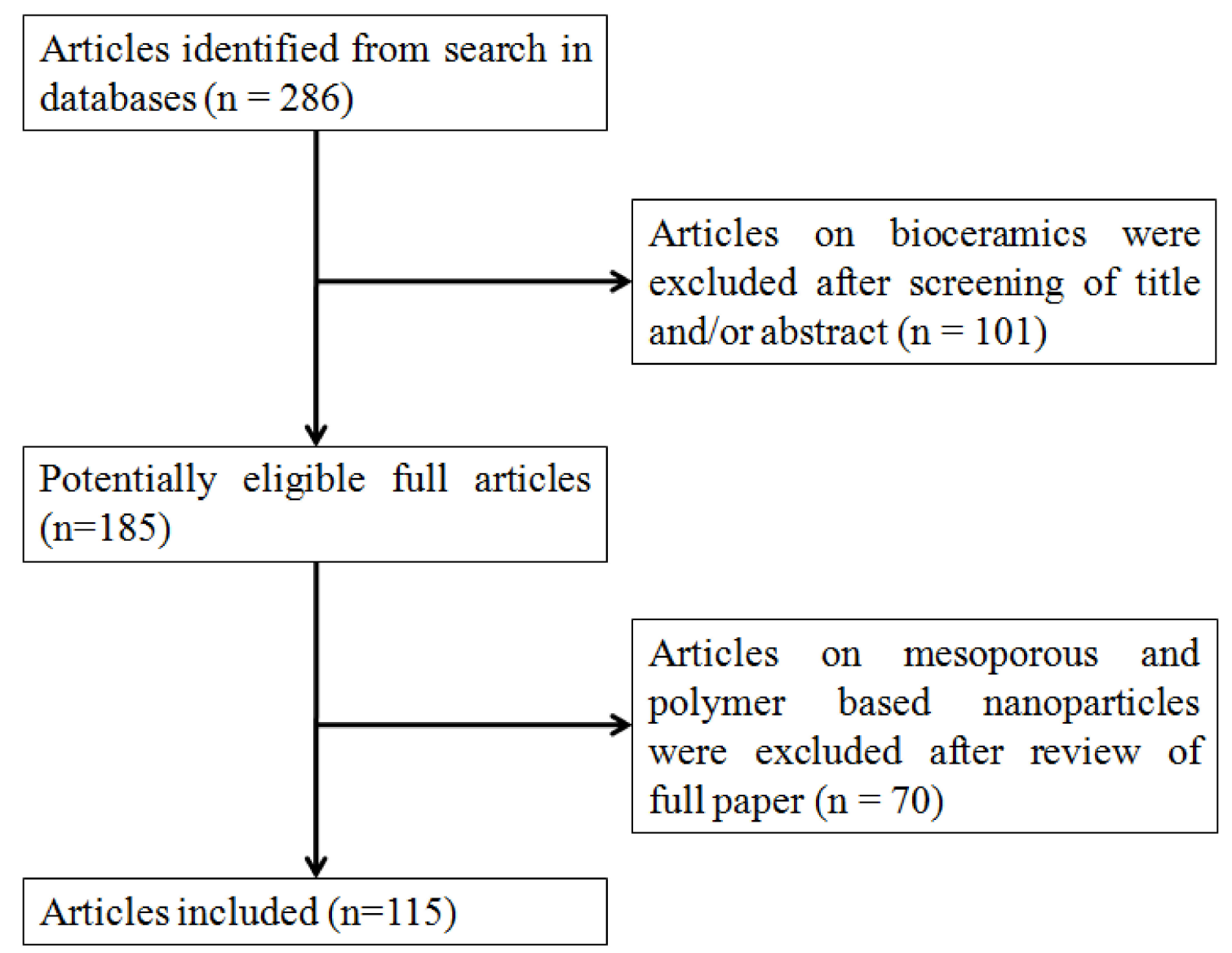

Scheme 1. Process for article selection based on the inclusion criteria.

\section{Copper}

Among many vital metals, copper is noteworthy due to its significant physiological role in enzymatic reactions and electron transfer associated energy generation. Copper nanoparticles (CuNPs) are biocompatible and possess enhanced antioxidant and antidiabetic activity advantageous for wound healing [35-37]. It can induce the migration and proliferation of endothelial cells and can also stimulate angiogenesis. Moreover, copper treated wounds exhibited enhanced tissue regeneration, thereby facilitating the healing process [38]. Hence, copper is considered as a promising metal to be incorporated in nanoscaffolds for bone tissue regeneration applications.

D'Mello et al. (2014) incorporated copper into chitosan scaffolds to enhance bone tissue regeneration [39]. Initially, chitosan sponges were prepared by dissolving chitosan in a $0.3 \mathrm{M}$ acetate buffer at a concentration of $2 \% w / v$ which was then lyophilized. Furthermore, copper-chitosan scaffolds were fabricated by reacting the chitosan solution with a $0.625 \mathrm{mM}$ copper solution for $4 \mathrm{~h}$. Pores $104 \pm 5 \mu \mathrm{m}$ in diameter in the chitosan scaffolds formed interconnecting networks, while the incorporation of copper in the scaffolds did not alter such micro-structural aspects. Uniform mineralized bone tissue formation was evident 4 weeks after implantation of copper-chitosan scaffolds into critical-sized calvarial defects ( $5 \mathrm{~mm}$ diameter) in Fisher 344 male rats. This enhanced osteogenesis might be attributed to the macroporous nature of the scaffolds that facilitated the infiltration of cells to migrate to the site of injury. Moreover, the walls of the porous matrix provided support for the attachment and anchoring of cells. Larger pore sizes allowed for adequate space for cell growth, proliferation, differentiation, and angiogenesis, resulting in better bone tissue development.

Zhang et al. (2016) reported enhanced osteoinductive properties of graphene oxidecopper nanocomposite (GO-Cu) coated porous calcium phosphate (CaP) scaffolds. GO 
was prepared by the oxidation of graphite [40]. Then, an aqueous $\mathrm{CuSO}_{4}$ solution reacted with GO and ascorbic acid at $60^{\circ} \mathrm{C}$ followed by centrifugation to recover the nanocomposites comprised of crystallized $\mathrm{CuO} / \mathrm{Cu}_{2} \mathrm{O}$ nanoparticles $\approx 30 \mathrm{~nm}$ in diameter. The nanoparticles were uniformly distributed onto the surface of the porous scaffolds and exhibited a sustained release of $\mathrm{Cu}$ ions as shown in Figure 1. The calcium phosphate cement (CPC) scaffolds with 70\% porosity, $5 \mathrm{~mm}$ diameter, $3 \mathrm{~mm}$ height, and $150-400 \mu \mathrm{m}$ pore diameters were immersed in $1.50 \mathrm{mg} \mathrm{mL}^{-1} \mathrm{GO}$ or a GO-Cu solution at $37{ }^{\circ} \mathrm{C}$ for $10 \mathrm{~min}$ and were vacuum dried to obtain nanocoated scaffolds. The GO-Cu coating not only enhanced the adhesion and osteogenic differentiation of rat bone marrow stem cells (BMSCs), but it also activated the Erk1/2 signaling pathway and upregulated the expression of hypoxia-inducible factor-1 alpha (Hif- $1 \alpha)$. It is significant to note that angiogenesis and osteogenesis are tightly coupled during bone development and regeneration where the Hif- $1 \alpha$ pathway plays a critical role. Wan et al. 2010 reported that the overexpression of the Hif- $1 \alpha$ subunit results in its accumulation in the cytoplasm, which then translocates to the nucleus and dimerizes with the Hif- $1 \beta$ subunit [41]. This dimer then binds to a highly conserved hypoxia-response element (HRE) within promoters of hypoxia-responsive genes. Functional HREs encode proteins involved in angiogenesis (VEGF, endothelin-1), maturation of red blood cells (erythropoietin and transferrin), energy metabolism (glucose transporter 1 and 3), and cell proliferation and viability (insulin-like growth factor 2, p21). This leads to an increase in the secretion of VEGF and BMP-2 proteins. Upon transplantation into critical-sized calvarial defects in rats, the GO-Cu-coated CPC scaffolds notably promoted both angiogenesis and osteogenesis. Phagocytosis of the GO-Cu nanocomposites by multinucleated giant cells indicated significant vascularized bone regeneration.

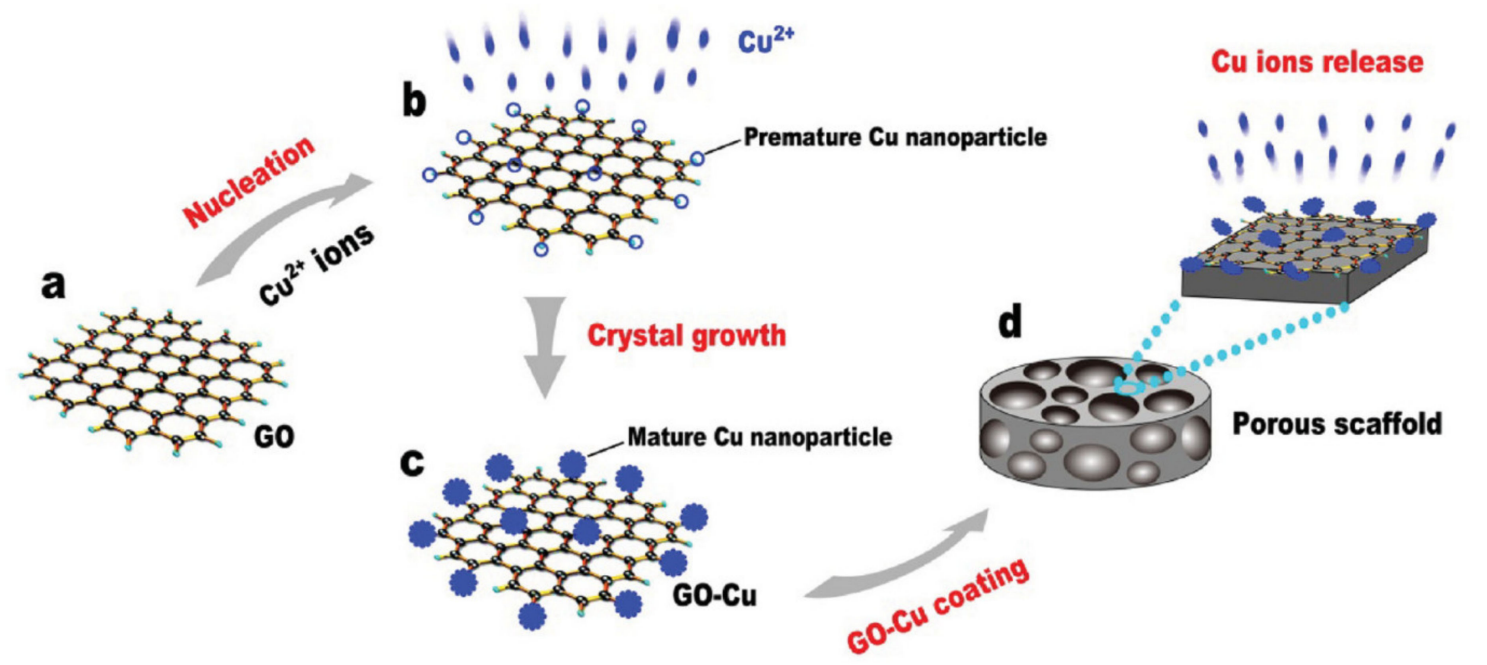

Figure 1. Schematic of the experimental protocol followed for the fabrication of GO-Cu-coated CPC scaffolds. (a) The GO pattern; (b) Premature Cu nanoparticles on GO films; (c) Mature nanoparticles on GO films; and (d) GO-Cu coated porous CPC scaffolds. Reproduced from [40], with permission of WILEY-VCH 2016.

Nanocomposites with a dual role of bone tissue regeneration as well as antimicrobial activity are more preferred biomaterials for orthopedics as they can promote bone healing as well as resist biofilm associated implant failure. Bari et al. (2017) incorporated copper within mesoporous bioactive glasses (MBGs) to facilitate both osteogenesis and angiogenesis apart from inhibiting bacterial growth [42]. The one-pot ultrasound-assisted sol-gel process was employed to modify the framework of a binary $\mathrm{SiO}_{2}-\mathrm{CaO}$ mesoporous glass with a copper ion concentration of 2 and 5\% mol denoted as Cu_MBG 2\% and Cu_MBG 5\%, respectively. In this method, calcium nitrate tetrahydrate and copper chloride were added to a methanolic cetyltrimethylammonium bromide (CTAB) solution which was further reacted with tetraethylorthosilicate (TEOS) under ultrasonication for $20 \mathrm{~min}$ followed by stirring at room temperature for $24 \mathrm{~h}$. The resulting precipitate was recovered, dried and 
eventually calcined at $600{ }^{\circ} \mathrm{C}$ for $5 \mathrm{~h}$ to obtain the final nanocomposite (Cu_MBG). $2 \%$ Cu_MBG uniformly spherical 170 to $200 \mathrm{~nm}$ diameter particles exhibited a worm like system of mesopores throughout the inner structure as seen in Figure 2. The Cu ions were evenly distributed within the nanocomposite. The 5\% Cu_MBG were also spherical but slightly bigger in size ranging from 180 to $230 \mathrm{~nm}$ with a core-shell morphology. The shell was composed of a regular mesoporous structure while the internal core showed larger and irregular cavities with more $\mathrm{Ca}$ and $\mathrm{Cu}$ content. The $\mathrm{Cu}$ _MBG nanoparticles exhibited a promising antibacterial effect against E. coli, S. aureus, and S. epidermidis. Further, the nanoparticles significantly inhibited and dispersed the S. epidermidis biofilm. It was speculated that this advanced material of a mesoporous nature can effectively treat bone defects.

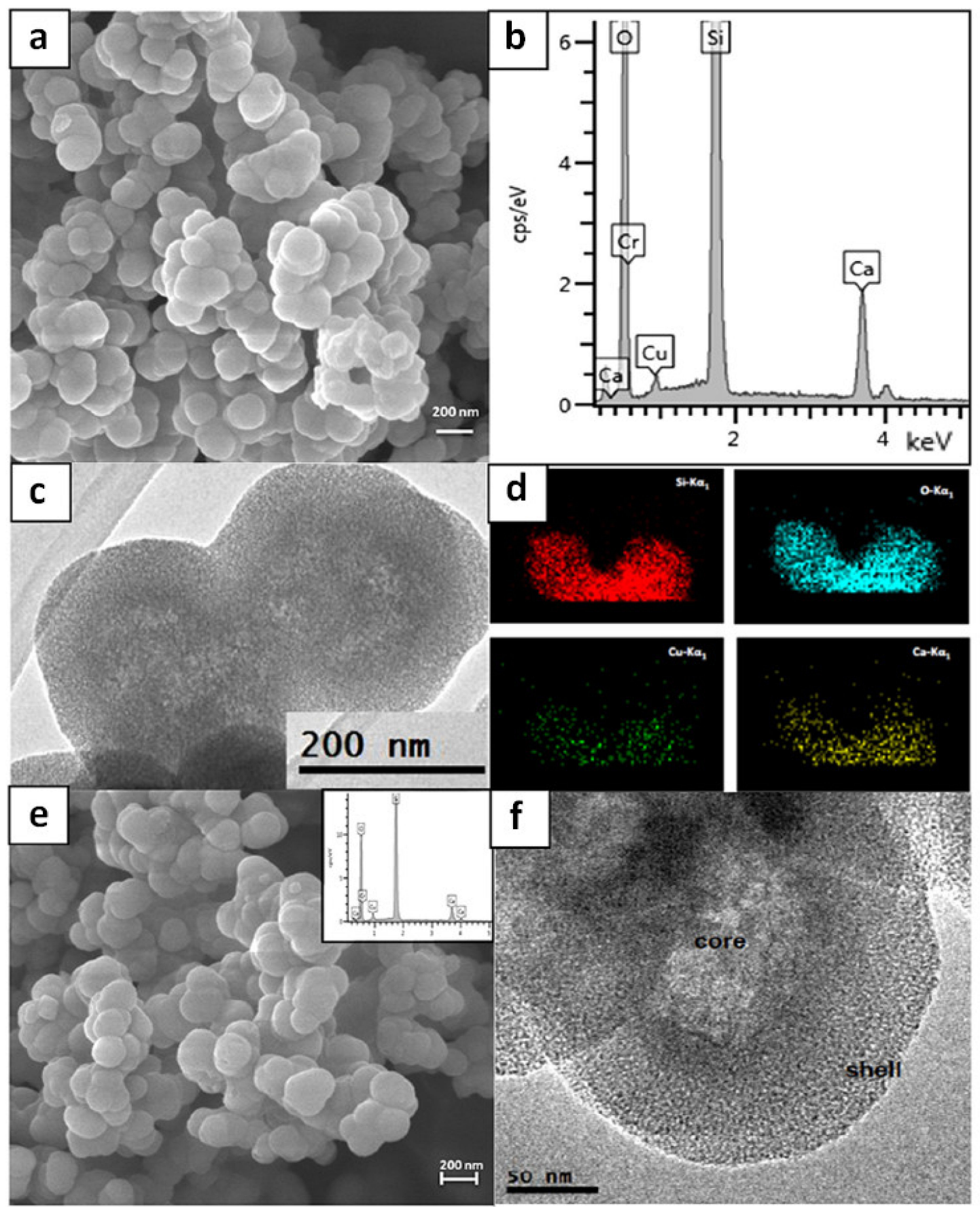

Figure 2. Scanning electron microscopic image of Cu_MBG 2\% (a), EDS spectrum (b), TEM image (c) and EDS mapping 
analysis of $2 \% \mathrm{Cu} \_\mathrm{MBG}(\mathrm{d}), \mathrm{Si}$ (red), $\mathrm{O}$ (blue), $\mathrm{Cu}$ (green) and $\mathrm{Ca}$ (yellow) were uniformly distributed in the nanoparticles; SEM image of 5\% Cu_MBG (e), related EDS spectrum (inset), and TEM image (f). Reproduced from [42], with permission of Elsevier 2017. Abbreviations: Cu_MBG, copper within mesoporous bioactive glasses.

\section{Gold}

Gold nanoparticles (AuNPs) are biocompatible and have shown tremendous therapeutic potential in the area of cancer, diabetes, other oxidative stress diseases, and tissue engineering [43]. AuNPs are being used for sensing, bioimaging, targeted drug delivery as well as photothermal and photodynamic therapies. Several top-down and bottom-up synthetic approaches have been employed to obtain tunable sizes and shapes. Since the bioactivity of AuNPs are largely size and shape dependent, processes are being optimized to obtain desirable morphological features. Green synthetic approaches employing bacteria, fungus, algae, plant extracts, and their metabolites aim to increase biocompatibility of the therapeutically promising AuNPs [44,45]. Moreover, their large surface area is ideal for multifunctionalization with drugs, targeting ligands and contrast agents.

AuNPs have also been used for developing scaffolds with promising biocompatibility and osteogenic potential. For example, Liang et al. (2019) fabricated a novel gold nanoparticle (AuNP)-loaded mesoporous silica nanoparticle (Au-MSNs) for accelerated bone regeneration [46]. MSNs were synthesized by reacting hexadecyl trimethylammonium bromide (CTAB) with $4 \mathrm{M} \mathrm{NaOH}$ and tetraethyl orthosilicate (TEOS) and then were recovered by centrifugation followed by calcination at $550{ }^{\circ} \mathrm{C}$ for $5 \mathrm{~h}$. Next, the MSN with amidogen was obtained by dissolving the MSNs in methylbenzene followed by refluxing at $80^{\circ} \mathrm{C}$ in the presence of $\mathrm{N}$-(amino-ethyl)-amino-propyl trimethoxy silane (APTES). AuNPs were separately formed by the reaction of $\mathrm{HAuCl}_{4}$ with a trisodium citrate solution at $100{ }^{\circ} \mathrm{C}$ for $20 \mathrm{~min}$ followed by the addition of polyvinylpyrrolidone (PVP). The resulting AuNPs were recovered, washed and reacted with MSNs for $12 \mathrm{~h}$ to obtain an Au-MSNs composite. Further, the chitosan scaffolds were immersed for $24 \mathrm{~h}$ in the Au-MSN solution to obtain Au-MSN coated chitosan scaffolds. Both MSNs and Au-MSNs were 80 to $110 \mathrm{~nm}$ in size with well aligned mesoporous structures.

However, in the case of Au-MSNs, several nanoparticles with a diameter of $15 \mathrm{~nm}$ were uniformly distributed across the surface of the MSNs. The Au-MSNs generated a favorable immune microenvironment by stimulating an anti-inflammatory response and promoting the secretion of osteogenic cytokines (IL-1ra, IL-10, and Arg) by Murine-derived RAW 264.7 cells. This resulted in more osteogenic differentiation in preosteoblastic MC3T3 cells as indicated by higher levels of osteogenic markers such as alkaline phosphatase (ALP) and calcium deposition. Similarly, the Au-MSNs also enhanced the formation of new bone in a critical-sized cranial defect site in rats. Hence, these novel gold supplemented nanoscaffolds promoted osteogenesis remarkedly better than conventional approaches, resulting in better bone tissue repair and regeneration.

Tsai et al. (2013) synthesized AuNPs using sodium citrate with an average size of $10.76 \pm 1.4 \mathrm{~nm}$ [47]. Upon treating MG63 osteoblast-like cells (human osteogenic sarcoma cells) with $1 \mathrm{ppm}$ and $10 \mathrm{ppm}$ of AuNPs, it was observed that most of the AuNPs aggregated and were localized in the late endosomes in cells which might be attributed to vesicle fusion as shown in Figure 3. Importantly, the AuNPs didn't induce apoptosis or necrosis. The appearance of specific nodule-like phenotypes along with the expression of bone associated genes in the MG63 cells, even after treatment with AuNPs, indicated regular osteogenetic differentiation without any toxicity or metabolic alteration. Hence, AuNPs based nanoscaffolds may provide biocompatible materials for improved orthopedic regenerative medicine applications. 


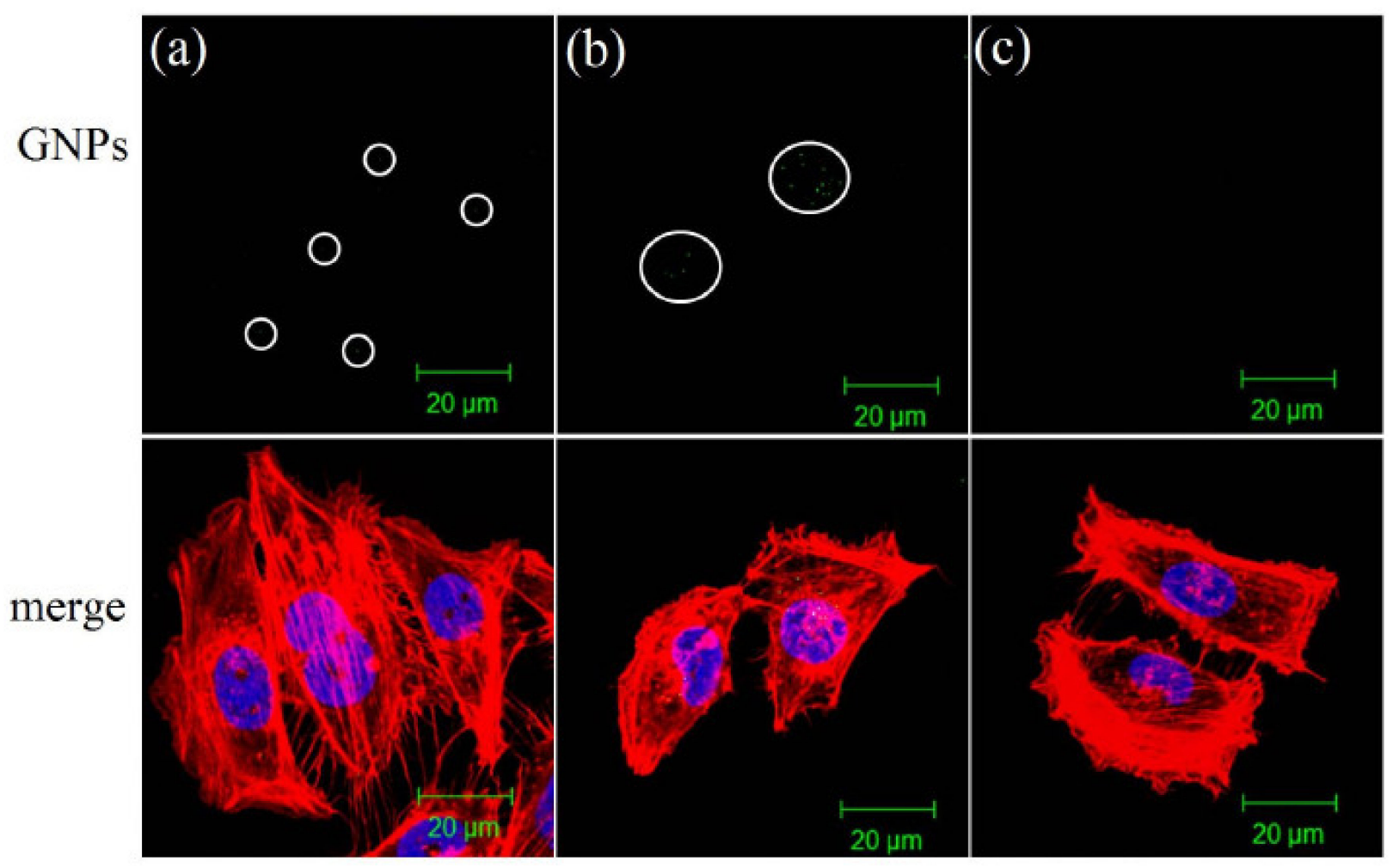

Figure 3. Laser scanning confocal microscope (LSCM) fluorescence images of MG63 cells after uptake of AuNPs. LSCM fluorescence images of (a) MG63 cells treated with AuNPs at a concentration of 1 ppm, (b) 10 ppm, and (c) normally cultured cells. Cytoskeletal F-actin (red) were stained with Texas Red-X phalloidin. Cell nuclei (blue) were stained with Hoechst 33258. The green spots in the circled areas are AuNPs. Reproduced from [47] under Creative Commons Attribution License.

The underlying mechanism for AuNPs osteogenic promotion was reported by Yi et al. 2010 [48]. The synthesized AuNPs were spherical in shape with an average diameter of $20 \mathrm{~nm}$ that showed a concentration dependent promoted osteogenic differentiation of MSCs. The AuNPs entered the cells by receptor mediated endocytosis after adsorption of serum protein onto the external surface of the nanoparticles. Figure 4 shows that the AuNPs were grouped into intracellular compartments in the cells, particularly inside the perinuclear compartments and vesicular structures close to the cell nucleus. The AuNPs modulated cellular signaling pathways by interacting with the cytosolic proteins. AuNPs treated cells showed a mechanical stress mediated marked enhancement in ALP activity, mineralized nodule formation, up-regulation of $\mathrm{p} 38$ protein, integrin family genes (integrin $\alpha 2$, integrin $\alpha 2 b$, integrin $\alpha 3$, integrin $\alpha \mathrm{M}$, and integrin $\alpha \mathrm{V}$ ), matrix metalloproteases (such as Mmp2, Mmp8, and Mmp9), cell-cell adhesion related genes (Cd36, Cdh11, and Vcam1), and the lineage commitment gene Runx2 along with other osteogenic markers (BMP1, BMP2, BMP4, OCN and Col1a2). Thus, it is now well established that osteogenic differentiation due to AuNP exposure can be attributed to mechanical stimuli-initiated signal transduction via the 338 MAPK pathway.

Zhang et al. (2017) established that the AuNPs which promoted the osteogenic differentiation of MSCs and osteoblasts were size dependent [49]. Interestingly, it was noticed that the treatment of human periodontal ligament progenitor cells (PDLPs) with smaller dimensions than the AuNPs (5 nm), significantly reduced alkaline phosphatase activity, mineralized nodule formation and expression of osteogenic genes. On the contrary, treatment with AuNPs of a comparatively larger size (13 and $45 \mathrm{~nm}$ ) resulted in the increased expression of osteogenic markers. Osteogenic differentiation was significantly promoted by $45 \mathrm{~nm}$ compared to $13 \mathrm{~nm}$ AuNPs. Further, the up-regulation of autophagy was facilitated by 13 and $45 \mathrm{~nm}$ AuNPs while $5 \mathrm{~nm}$ AuNPs blocked the same events clearly indicating that the AuNPs modulated the osteogenic differentiation of PDLPs in a size-dependent manner, 
with autophagy playing a major role. Hence, the morphological features of AuNPs should be taken into consideration when designing scaffolds for periodontal bone regeneration.
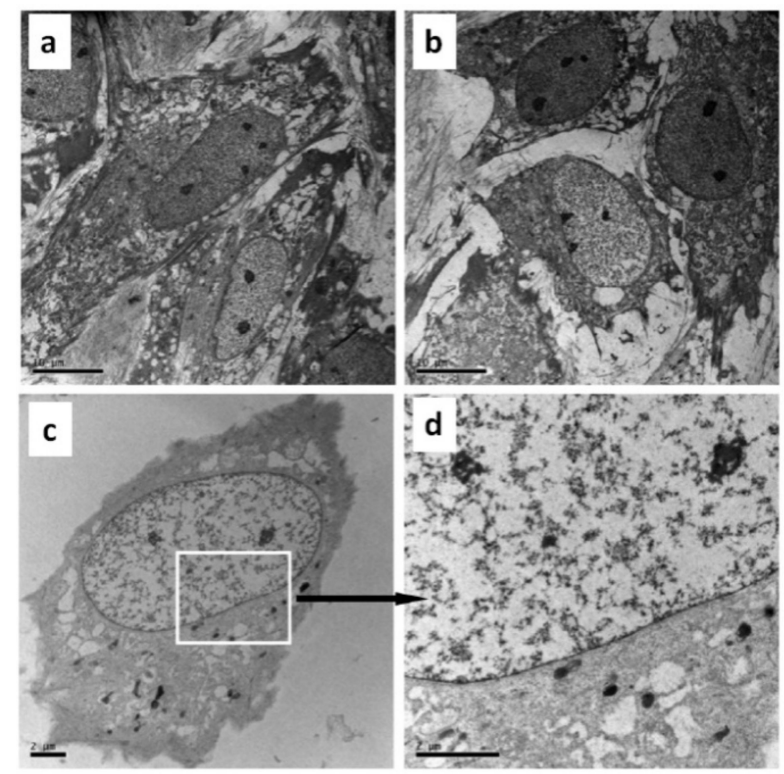
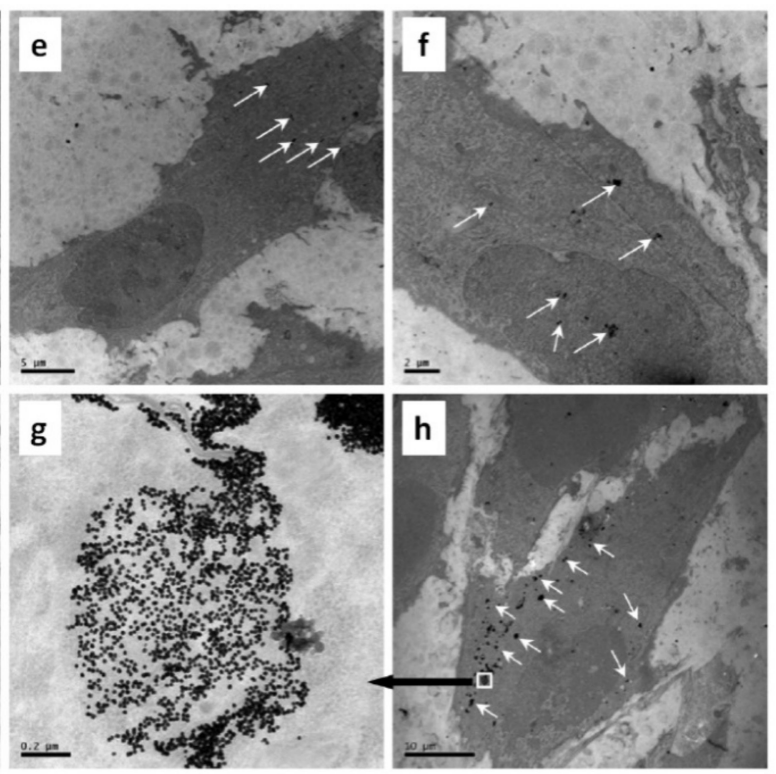

Figure 4. Transmission electron microscope (TEM) images of the internalization of AuNPs. (a-d): Cells were treated with OS as a control; (e-h): cells were treated with OS and $1.0 \mathrm{nM}$ AuNPs. Arrows indicate AuNPs. The images are representative of three independent experiments. Reproduced from [48], with permission of American Chemical Society 2010. Abbreviation: OS-osteogenetic induction supplement.

AuNPs and alloys of gold can be attractive nanomaterials for promoting bone tissue regeneration. For example, Zhang et al. (2019) fabricated porous gold-palladium (pAuPd) alloy nanoparticles to facilitate bone regeneration due to hyperthermia (via a mild localized heating effect) up to $40-43^{\circ} \mathrm{C}$ under NIR laser irradiation as shown in Figure 5 [50]. An effective wet-chemistry strategy was used for the synthesis of pAuPds that involved ascorbic acid, phloroglucinol, citric acid, sodium citrate, or glucose as reducing agents. Nearly spherical nanostructures with a solid core and densely branched shells were obtained when the molar ratio between $\mathrm{Pd}$ and Au was equivalent to 2:2. The pAuPds were considered safe as they didn't display any cytotoxicity up to concentrations as high as $200 \mu \mathrm{g} \mathrm{mL}^{-1}$. Their application in photothermal therapy (PTT) was confirmed as the temperature of preosteoblast-MC3T3-E1 cells treated with pAuPds increased upon exposure to near infrared (NIR) irradiation. Further, pAuPds were used for checking their healing effect on critical-sized cranial defects ( $8 \mathrm{~mm}$ in diameter) in rats. It is significant to note that after being engulfed by cells, pAuPds showed mild hyperthermia under NIR treatment that greatly accelerated cell proliferation and bone regeneration sealing $97 \%$ of the cranial defect by newly formed bone after six weeks of PTT. It was speculated that mild local heat could activate the Wnt signaling pathway for triggering enhanced in situ bone regeneration.

More recently, Zhang et al. (2021) reported superior osteogenic differentiation by PEGylatedAuNPs [51]. In this study, AuNPs of various sizes were synthesized by two different methods. Gold ions were reduced to AuNPs $4 \mathrm{~nm}$ in diameter in the presence of $\mathrm{NaBH}_{4}$ and trisodium citrate. On the other hand, AuNPs $18 \mathrm{~nm}$ and $45 \mathrm{~nm}$ in size were fabricated using a citrate reduction method. The as-synthesized AuNPs were further PEGylated using poly(ethylene glycol) thiol via the high affinity site of the -SH groups for AuNPs. The resulting nanoparticles of all three different sizes exhibited excellent biocompatibility and osteogenic differentiation properties on MC3T3-E1 cells which were found to be a function of their size. PEGylated AuNPs $45 \mathrm{~nm}$ in size enhanced alkaline phosphatase (ALP) activity, mineralized nodule formation and the expression of osteogenic marker genes as well as up-regulated $\beta$-catenin and $\mathrm{p}$-GSK-3 $\beta$ genes, compared with 
the $18 \mathrm{~nm}$ group. On the other hand, nanostructures $4 \mathrm{~nm}$ in size significantly reduced osteogenic effects. The molecular events indicated that the activation of the $\mathrm{Wnt} / \beta$-catenin signaling pathway might be the underlying mechanism for the induction of osteogenic differentiation by larger PEGylated AuNPs, while smaller nanostructures inhibited such action. Further, AuNPs conjugated with PEG-hydrogel resulted in the rapid regeneration of bone in rabbits with 4-mm femur defects.

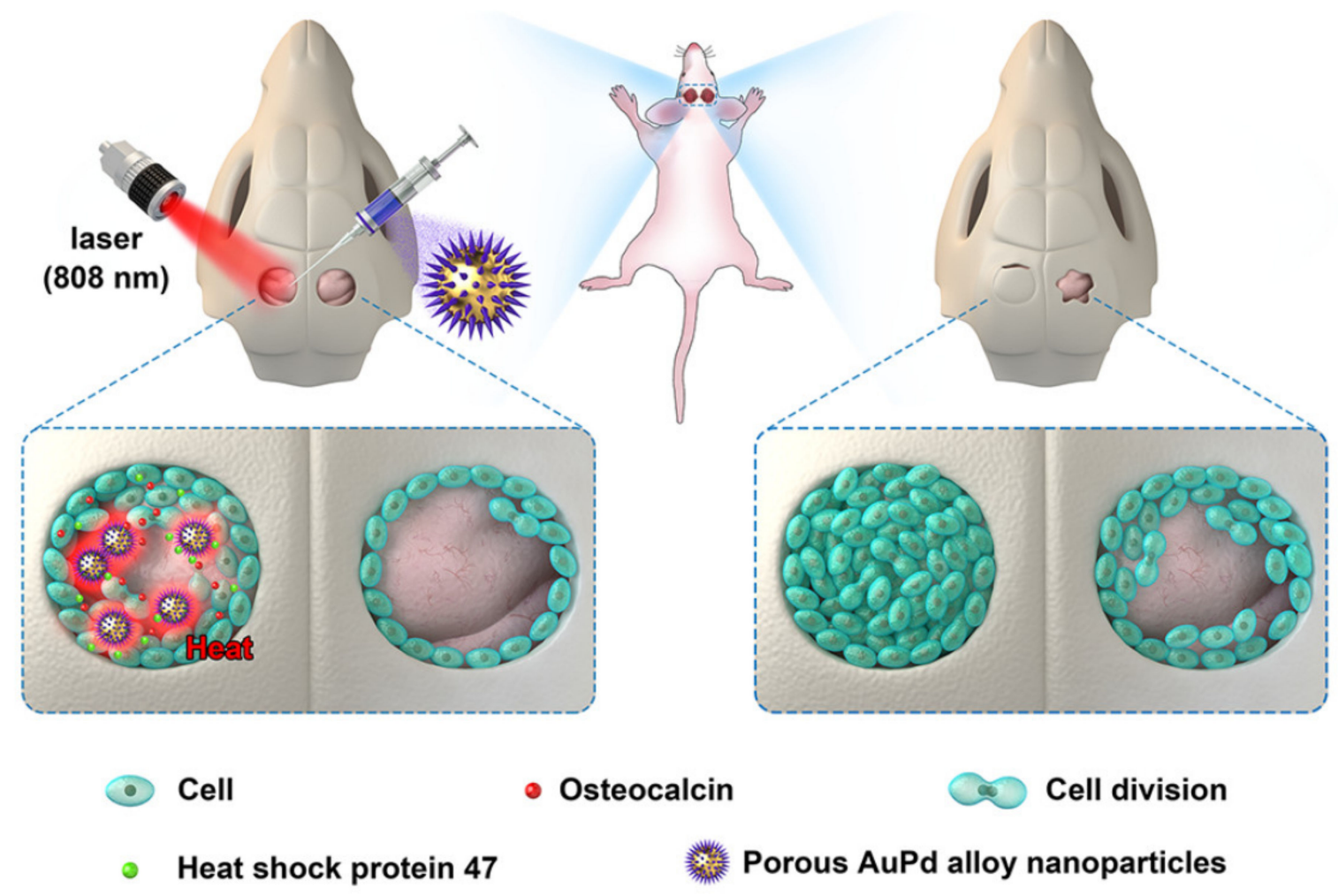

Figure 5. Schematic illustration of pAuPds for the PTT of cranial defects. Reproduced from [50], with permission of American Chemical Society 2019. Abbreviation: PTT, photothermal therapy.

\section{Magnetic Nanoparticles}

Although various metals have been used for developing scaffolds for supporting bone tissue regeneration, magnetic materials are considered much more attractive due to their mobility in response to a magnetic field [5,52]. Magnetic iron oxide nanoparticles (IONPs) can be multifunctionalized with growth factors, drugs, antibodies, or other biological agents for efficient targeting, hyperthermia, triggered release and imaging [53].

In one of the studies, Bock et al. (2010) fabricated a magnetic biomimetic scaffold using ferrofluids containing aqueous dispersions of magnetite nanoparticles (200 $\mathrm{nm}$ in size) [54]. The scaffolds further contained hydroxyapatite (HA) and collagen (COLL) crosslinked with 1,4-butanediol diglycidyl ether (BDDGE), as homogeneous, micro- and macroporous pellets (diameter $12.2 \pm 0.8 \mathrm{~m}$ and height $4.7 \pm 0.8 \mathrm{~mm}$ ). Similarly, scaffolds referred to as COLL contained $100 \%$ collagen that were homogeneously formed into porous pellets (diameter $12.3 \pm 1 \mathrm{~mm}$, height $2.8 \pm 0.9 \mathrm{~mm}$ ). These magnetic scaffolds supported the adhesion and proliferation of human bone marrow stem cells in vitro.

Cai et al. (2015) also reported enhanced osteogenic differentiation under a moderateintensity (1 mT-1 T) static magnetic field (SMF) when treated with electrospun nanofibrous structures made out of poly(L-lactide) (PLLA) and ferromagnetic $\mathrm{Fe}_{3} \mathrm{O}_{4}$ nanoparticles (NPs) [55]. The PLLA/ $\mathrm{Fe}_{3} \mathrm{O}_{4}$ composite nanofibers 600 to $1000 \mathrm{~nm}$ in diameter could significantly increase cell adhesion, and promote the proliferation and osteogenic differentiation of MC3T3-E1 cells. Increased ALP activity and calcium deposition in 
treated cells further confirmed the positive role of PLLA $/ \mathrm{Fe}_{3} \mathrm{O}_{4}$ composite nanofibers for osteogenic differentiation.

Advancements in the area of nanotechnology and nanomedicine have led to the development of nanoinks ideal for 3D printing of tissues and organs. Rational tuning of the porosity and surface properties of 3D printed materials help to mimic the tissue microenvironment $[56,57]$. Although, iron based magnetic nanomaterials are ideal for bone healing, the uncontrollable architecture and stiffness of the nanostructures achieved during conventional synthesis have been major limitations. This problem was addressed by Yang et al. (2018) where a 3D printing technique was employed to control the macropore structure of scaffolds more precisely [58]. Figure 6 shows the morphological features of the $\mathrm{HA}$ coating on the Fe scaffolds under various experimental conditions. Interestingly, the $\mathrm{pH}$ value of the initial solution played a major role in determining the shape of the HA coating. A nanosheet structured HA was obtained at $\mathrm{pH} 6$ (Figure $6 \mathrm{~b}$ ) while a nanorod structured $\mathrm{HA}$ was obtained at $\mathrm{pH} 9$ (Figure 6c) and $\mathrm{pH} 13$ (Figure 6d). These innovative scaffolds with $66.2 \pm 4.9 \%$ porosity significantly improved the viability, alkaline phosphatase (ALP) activity and osteogenic differentiation of rabbit bone marrow mesenchymal stem cells (rBMSCs) on the scaffolds.

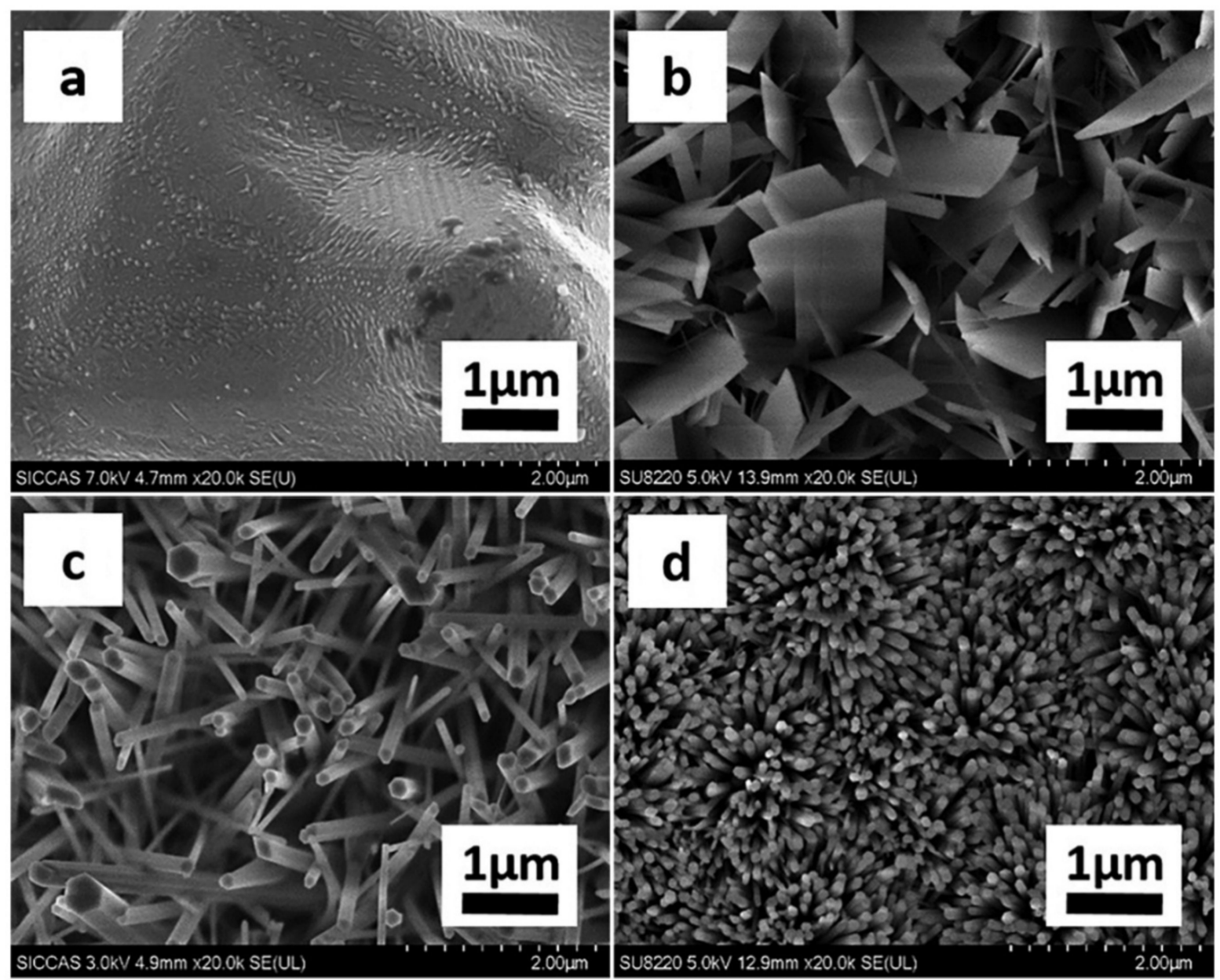

Figure 6. Scanning electron microscope (SEM) images of HA coated scaffolds prepared in an initial solution with different $\mathrm{pH}$ values at $120^{\circ} \mathrm{C}$ for $12 \mathrm{~h}$ : (a) A Fe scaffold without HA coating and (b-d) HA coating generated at $\mathrm{pH}$ 6, 9, and 13, respectively. Reproduced from [58], with permission of American Chemical Society 2018. Abbreviation: HA, Hydroxyapatite.

More recently, Zhao et al. (2021) fabricated superparamagnetic iron oxide nanoparticles (SPIONs) encapsulated into poly-lactic-co-glycolic acid (PLGA) microspheres to 
regulate the osteogenic differentiation of bone mesenchymal stem cells (BMSCs) [59]. In this study, three different types of PLGA microspheres (PFe-I, PFe-II, and PFe-III) were synthesized with the amount of loaded SPIONs equivalent to $1.83 \%, 1.38 \%$, and $1.16 \%$, respectively. The microspheres were in a range from $160 \mu \mathrm{m}$ to $200 \mu \mathrm{m}$ with notable porous and rough surfaces. The PFe-II microspheres served as ideal surfaces as indicated by the enhanced adhesion of BMSCs after two days of co-culture. Remarkable osteoblast differentiation of BMSCs as indicated by a high expression of ALP, COL-I, OPN, and OCN was observed after 2 weeks of co-culture. Under an external magnetic field, notable bone mineral density (BMD, $263.97 \pm 25.99 \mathrm{mg} / \mathrm{cm}^{3}$ ), trabecular thickness (TB. TH, $0.58 \pm 0.08 \mathrm{~mm}$ ), and bone tissue volume/total tissue volume (BV/TV, $78.28 \pm 5.01 \%$ ) were found six weeks after surgical implantation of PFe-II microspheres into femoral rat bone defects.

Wang et al. (2016) showed osteogenic differentiation of hBMSCs can be promoted by IONPs in response to the MAPK pathway [60]. Initially, the IONPs were synthesized by employing a classic chemical co-precipitation method using ferrous chloride hexahydrate and ferrous chloride tetra-hydrate. Further, the nanoparticles were modified to obtain an IONP core and polyglucose-sorbitol-carboxymethy ether (PSC) shell. The core-shell type magnetic nanoparticle exhibited an average size of $7 \mathrm{~nm}$. Cellular uptake of IONPs by hBMSCs was time- and dose-dependent where $100 \mathrm{mg} / \mathrm{mL}$ of the particles were most suitable for promoting hBMSCs osteogenic differentiation. A notable (4-12 fold) up-regulation of osteogenic markers, such as ALPL (ALP liver), RUNX2 (runt-related transcription factor 2, also known as CBFA1), BMP2 (bone morphogenetic protein 2), OMD (osteomodulin), FOXO1 (forkhead box O1) and ATF4 (activating transcription factor 4), was observed. On the other hand, the MSC markers, such as MCAM (melanoma cell adhesion molecule), ENG (endoglin), CLCF1 (cardiotrophin-like cytokine factor 1), TPM1 (tropomyosin 1) and CD44, were down-regulated 2.5-5 fold. Likewise, mRNA expression of other significant genes like FGFR1, KRAS, MAP3K8 (Tp12/Cot), RPS6KA1 (p90RSK1) and RPS6KA3 (p90RSK3) were all up-regulated, whereas MAP2K2 (MEK2) was down-regulated suggesting the role of the classical MAPK pathway.

A static magnetic field (SMF) stimulated osteoblastic differentiation and bone formation much better when magnetic nanoparticles were incorporated into the scaffolds [61]. Magnetism has recently been implicated to play a significant role in the regulation of cell responses. A magnetic nanocomposite scaffold comprised of polycaprolactone and magnetic nanoparticles significantly promoted primary mouse calvarium osteoblastic differentiation as noted by the simultaneous expression of bone-associated genes (Runx2 and Osterix) and alkaline phosphatase activity. Integrin signaling pathways were activated showing the up-regulation of focal adhesion kinase, paxillin, RhoA, mitogen-activated protein kinase, and nuclear factor-kappaB, along with the enhanced expression of BMP-2 and phosphorylation of Smad1/5/8. Furthermore, apart from osteogenic promotion, the $\mathrm{SMF} /$ magnetic scaffolds also stimulated the angiogenic responses of endothelial cells with a simultaneous expression of vascular endothelial growth factor (VEGF) and angiogenin-1 genes. Capillary tubes were also formed upon treatment. Upon implantation into mouse calvarium defects, the magnetic scaffolds remarkably promoted new bone formation after six weeks. Considering their advantages and enhanced biocompatibility, magnetic nanoparticles can definitely serve as a good candidate for developing nanometal based scaffolds for osteogenic induction and bone tissue regeneration.

\section{Platinum and Palladium}

Among various noble metal nanostructures, platinum nanoparticles (PtNPs) and palladium nanoparticles (PdNPs) are most noteworthy due to their unique therapeutic properties that can be used for numerous antimicrobial, bioengineering, and biosensing applications. These nanoparticles are known to ameliorate oxidative stress by scavenging reactive oxygen species (ROS) which is critical to prevent several diseases [62-64]. Hence, these medically significant nanoparticles can protect one from neurodegenerative disorders, such as Alzheimer's disease, and also protect cells from oxidation-induced inflammation 
and induced bone loss by decreasing osteoclastogenesis [65]. However, less work has been done towards the incorporation of PtNPs and PdNPs for bone tissue regeneration.

In one study, calcium phosphate platinum nanoparticle (CPs-PtNPs) scaffolds were fabricated by heat sintering where a poly vinyl alcohol solution $(2 \mathrm{wt} \%)$ was used to create a ceramic slurry and $2.5 \%$ glutaraldehyde was used as a cross-linker. The casted slurry was initially dried at $100{ }^{\circ} \mathrm{C}$ for $24 \mathrm{~h}$ followed by sintering at $400{ }^{\circ} \mathrm{C}$. Superior porosity between $30-35 \%$ with pore sizes between 100 to $400 \mu \mathrm{m}$ was found in the scaffolds designed with $20 \mathrm{wt} \%$ CPs. The scaffolds were biodegradable and $10 \%$ PtNPs significantly enhanced cell attachment and proliferation on the scaffold surface [65].

In another study, novel hybrid 3D scaffolds were constructed which were composed of nanohydroxyapatite crosslinked with chitosan in a matrix of poly (lactic acid) nanofibers (PLA) and doped with PtNPs, AuNPs, and $\mathrm{TiO}_{2} \mathrm{NPs}$ together [66]. The PtNPs with sizes ranging from 10 to $20 \mathrm{~nm}$ with round, square and triangular shapes were homogeneously dispersed in the scaffold matrix due to their high affinity for the PLA fibers creating a "spiderweb-like" structure. The nanostructures enhanced the biomineralization process, cell adhesion, cell proliferation and osteogenic differentiation in MG-63 cells. Hence, these nanoparticles may help provide appropriate architectural requirements for numerous bone-tissue regeneration applications.

PdNPs along with polypyrrole (PPy; a conductive polymer) were non-covalently functionalized on two-dimensional reduced graphene oxide (rGO) in order to fabricate a Pd/PPy/rGO nanocomposite (NC) scaffold for bone tissue engineering [67]. 2-5 nm PdNPs were uniformly dispersed and strongly anchored on the PPy/rGO surface. It inhibited biofilm formation by bacteria, such as E. coli, B. subtilis, P. aeruginosa, and $K$. pneumoniae indicating its promise to resist biofilm associated implant failure. Further, the biocompatible scaffold promoted the proliferation of Saos- 2 cells. The NC substrates supported the development of osteo (Saos-2) cells which was indicated by the attachment of more osteoblasts to the walls of Pd/PPy/rGO after seven days of incubation.

Calabrese et al. (2020) reported that multi-metal nanoparticle-functionalized hydroxyapatite scaffolds could improve bone regeneration [68]. The cylindrical magnesium doped hydroxyapatite (Mg-HA) scaffolds $8 \mathrm{~mm}$ in diameter and $5 \mathrm{~mm}$ in height were composed of a bilayer structure where the upper layer ( $3 \mathrm{~mm}$ in depth) was made of equine type I collagen (Coll) that was deposited on a second layer ( $2 \mathrm{~mm}$ depth) comprised of a mineralized blend of type I Coll (30\%) and 70\% of Mg-HA. The collagenous layer in the scaffold had interconnected pores and larger channels with diameters up to $300 \mu \mathrm{m}$ and $600 \mu \mathrm{m}$, respectively. Further, these scaffolds were functionalized with gold nanorods (AuNRs), palladium nanoparticles (PdNPs) and maghemite nanoparticles (MAG NPs) which were $15 \pm 5 \mathrm{~nm}$, $3.4 \pm 1 \mathrm{~nm}$ and $10 \mathrm{~nm}$ in diameter, respectively. MAG nanofunctionalization substantially improved adipose-derived mesenchymal stem cell (hADSCs) proliferation up to $70 \%$. However, both PdNPs and AuNRs inhibited cell growth up to $89 \%$ and $94 \%$, respectively, which was probably attributed to the cytotoxic effects for both PdNPs and AuNRs.

Similarly, Heidari et al. (2020) reported palladium supplemented hybrid ZnOhydroxyapatite nanocomposite-based scaffolds where chitosan was used as a binder [69]. The $\mathrm{HA} / \mathrm{ZnO} / \mathrm{Pd}$ nanoparticles were irregular in shape with an average particle size of $70 \mathrm{~nm}$. The PdNPs distributed on the surface of HA/ZnO were smaller than $10 \mathrm{~nm}$. However, the supplementation of the nanoparticles significantly reduced the number of viable human dental pulp stem cells (hDPSCs) indicating their low biocompatibility. On the other hand, the scaffolds showed notable inhibition of Pseudomonas aeruginosa which is a potent nosocomial pathogen responsible for post-surgical complications.

\section{Silver}

Silver nanoparticles (AgNPs) have significant antimicrobial properties that make them more suitable to introduce into scaffolds to resist post-surgical pathogenic infections [70,71]. Various physical and chemical biological methods have been employed to synthesize AgNPs with well-defined sizes and shapes. Similarly, the synthesis of biocompatible 
AgNPs was reported using bacteria, fungi, algae and medicinal plants [72-75]. Thus, the incorporation of nanostructured silver and their alloys into scaffolds at sub lethal dosages can enhance the shelf life of the material and possibly prevent post-operative pathogenic infections [76,77]. AgNPs are well known microbicidal agents and are used in implants to avoid biofouling due to bacterial biofilm formation. Hence, they can be used for surface modification and developing microbe resistant coatings. Cao et al. (2017) reported titanium supported AgNPs for the promotion of osteogenesis [78]. Initially, AgNPs were in situ fabricated and immobilized onto titanium by using a plasma immersion ion implantation process. Three nanoparticle coated supports denoted as Ti-Ag1, Ti-Ag2, and $\mathrm{Ti}-\mathrm{Ag} 3$ were generated by silver plasma immersion ion implantation (Ag PIII) at $20 \mathrm{kV}$ for $0.5,1.0$, and $1.5 \mathrm{~h}$, respectively. The particle diameters for the Ti-Ag1 and Ti-Ag2 groups were in the range of $4-8$ and $4-19 \mathrm{~nm}$, respectively, whereas the Ti-Ag3 group could be divided into two subranges, i.e., $4-7$ and $9-13 \mathrm{~nm}$. Rat bone marrow stem cells (BMSCs) grown on Ag PIII treated groups expressed higher levels of filamentous F-actin indicating better cell adhesion. In the presence of Ti-Ag3, enhanced expression of osteogenic markers, like alkaline phosphate (ALP) and osteocalcin (OCN), was evident after seven days. Further, expression of the integrin $\alpha 5$ was up-regulated when BMSCs were cultured on Ag PIII groups from day one to day seven indicating a population-dependent capability of the nanomaterial for activating the integrin $\alpha 5$ orchestrated MAPK/ERK signal cascade resulting in superior osteoblast differentiation. In order to determine the influence of AgNPs immobilized on titanium on osteointegration, indwelling cylindrical implants were used in the femurs of rats followed by sequential labelling with fluorescent dyes as illustrated in Figure 7. The Ti-Ag3 group exhibited promising osteointegration as the implants were completely covered with new bone as shown in Figure 7b. Calcein (as indicated by the green color) was injected at the sixth week which revealed significant thickening of the bone around the Ti-Ag3 implants. Also, bone remodeling was confirmed by a large overlapping region around the Ti-Ag3 group after the six-week period. Hence, these nanomaterials can be used for engineering durable implants with antibacterial and osteogenic potential.

Further, Castiglioni et al. (2017) reported the use of AgNPs for orthopedic applications where Saos-2 cells were found to be rather resistant to the cytotoxic effects of AgNPs alone, with a half maximal inhibitory concentration $\left(\mathrm{IC}_{50}\right)$ of approximately $25 \mu \mathrm{g} / \mathrm{mL}$ [79]. Moreover, after a month-long treatment, the hMSCs adapted to the presence of the AgNPs, which was attributed to the upregulation of hsp70 resulting in the restoration of normal cell proliferation. Interestingly, Jiang et al. (2016) reported a concentration and time dependent release of $\mathrm{Ag}^{+}$ions from a porous nanohydroxyapatite/polyurethane (n-HA/PU) composite scaffold which was incorporated with silver phosphate $\left(\mathrm{Ag}_{3} \mathrm{PO}_{4}\right)$ [80]. The release of ions continued even beyond three weeks and, thus, led to strong bactericidal effects against Staphylococcus aureus and Escherichia coli. The scaffolds facilitated the proliferation and adherence of MG63 cells, derived from human osteosarcoma and expressed characteristic features of osteoblasts, indicating its cytocompatibility and potential strong use for infection-associated bone defect repair.

Another powerful strategy to develop an antimicrobial bone tissue regenerating scaffold was reported by Jin et al. (2018) where electrospun silver ion-loaded calcium phosphate/chitosan antibacterial composite fibrous membranes were used [81]. Although an initial burst release was observed within the first day, augmentation of soaking time thereafter could control the amount of the $\mathrm{Ag}^{+}$released from nanofiber membranes. A strong inhibitory effect was observed against Porphyromonas gingivalis, which is the main pathogenic bacteria of peri-implantitis or periodontitis. Likewise, the membranes significantly inhibited the adhesion of Streptococcus mutans. Further, the membranes promoted the attachment of BMSCs which could greatly spread and grow cells on the membranes as shown in Figure 8. As the fibrous framework of the biodegradable polymer membrane, the micro-nanostructure can act as an ECM for improved cell attachment and adhesion. 


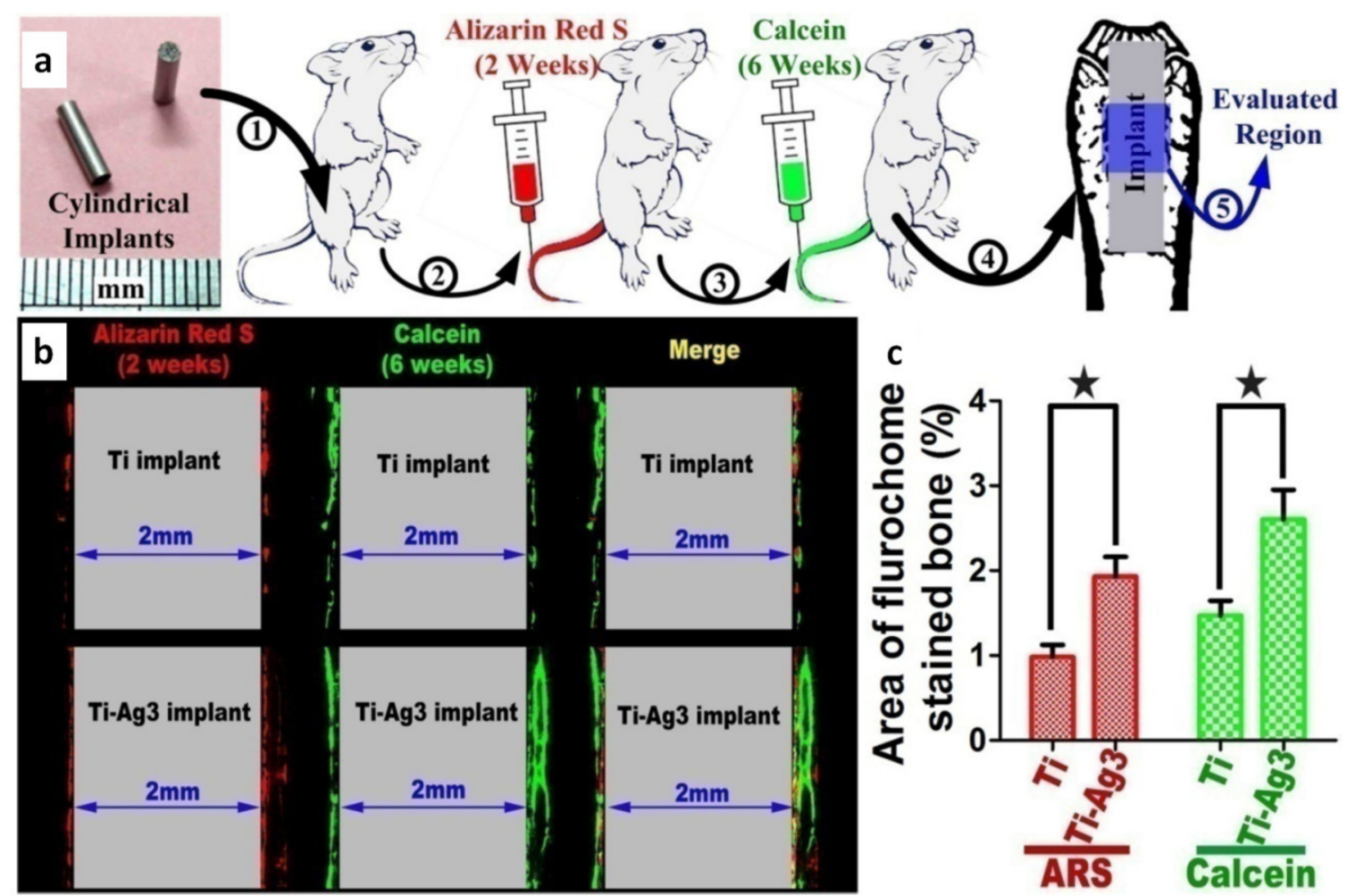

Figure 7. Immobilized AgNPs accelerated the osteointegration properties of titanium: (a) schematic of the surgical procedure, (b) sequential fluorescent labelling of the implant-bone boundaries of Ti and the Ti-Ag3 group, (c) percentage of new bone stained with Alizarin Red S (ARS) and calcein in (b); $\star$ represents $p<0.05$. Reproduced from [78], with permission American Chemical Society 2017.

Biocompatible natural rubber latex (NRL) can also be used for delivering AgNPs for bone regeneration. Marques et al. (2020) incorporated AgNPs 10-20 nm in size in the NRL membrane which exhibited enhanced bone tissue regeneration in rat calvaria bone defects [82]. Osteogenic activity was prominent mostly on the edges of the bone defect with the formation of short primary bone trabeculae near the wall of the defect. Also, the defects were progressively filled with connective tissue during the process of bone neoformation.

Natural antibacterial polymers (like silk fibroin combined with nanohydroxyapatite hydrogels) were supplemented with AgNPs and AuNPs in order to achieve superior bone regenerative properties [83]. Spherical monodispersed AgNPs and AuNPs with a size distribution ranging from 12.7 to $69.1 \mathrm{~nm}$ and from 9.3 to 54.7, respectively, were synthesized and combined using a silk fibroin solution derived from the cocoons of a Bombyx mori silkworm. Hydrogels with AgNPs exhibited very high antimicrobial activity against S. aureus, S. epidermidis, E. coli and P. aeruginosa. Hydrogels with AgNPs at concentrations up to $0.5 \%$, and the materials with AuNPs, supported the attachment and spreading of osteoblasts, with elongated morphologies and superior cell-to-cell contacts.

In another interesting study, Zhang et al. (2015) revealed the underlying mechanism behind the osteogenic effects of AgNPs [84]. Collagen scaffolds were developed with chemically synthesized AgNPs which exhibited early closure of a wound in a mouse femoral facture model that was attributed to the formation of a fracture callus. It was hypothesized that the AgNPs may promote the formation of the callus and the subsequent joining of the fractured bone via multiple routes: (i) chemoattraction of MSCs and fibroblasts to migrate to the fracture site; (ii) induction of MSC proliferation; and (iii) induction of the osteogenic differentiation of MSCs via activation of TGF- $\beta$ /BMP signaling in MSCs. 

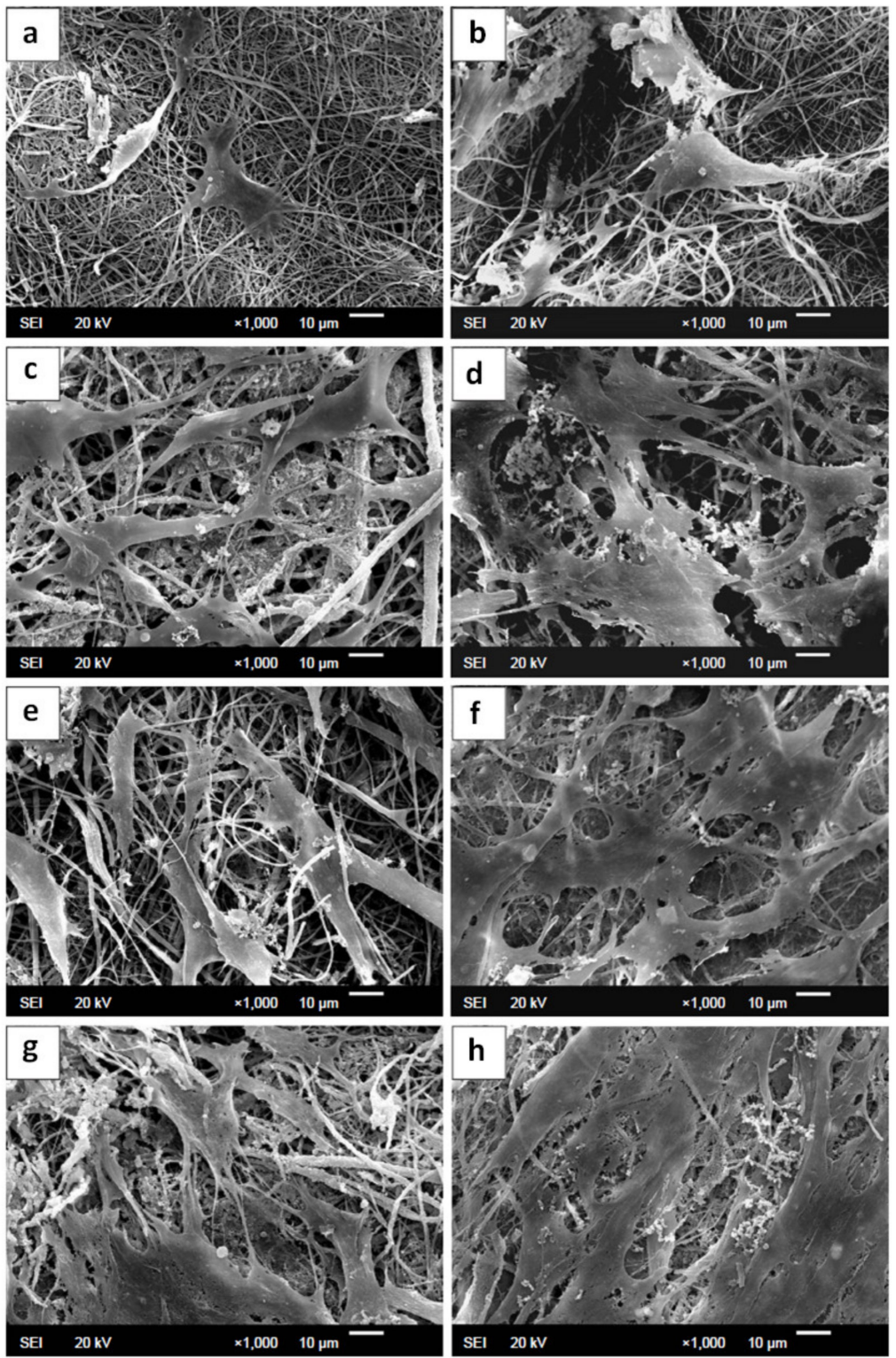

Figure 8. Scanning electron microscope (SEM) images of BMSCs on the surface of (a,b) CS, (c,d) A0, and $(\mathbf{e}, \mathbf{f}) \mathrm{A} 1$ and $(\mathbf{g}, \mathbf{h}) \mathrm{A} 2$ after $(\mathbf{a}, \mathbf{c}, \mathbf{e}, \mathbf{g}) 4$ days and $(\mathbf{b}, \mathbf{d}, \mathbf{f}, \mathbf{h}) 7$ days of incubation. Abbreviations: BMSCs, bone marrow stromal cells; CS, chitosan; SEM, scanning electron micrograph. Reproduced from [81], with permission of Jin et al. 2018. Abbreviations: CS, chitosan; A0, Ratio of CS to calcium phosphate is 4:1 and silver content is 0; A1, Ratio of CS to calcium phosphate is 4:1 and silver content is $0.075 \%$; A2, Ratio of CS to calcium phosphate is $4: 1$ and silver content is $0.144 \%$.

\section{Strontium}

Although various metal-based implants have been developed, they often fail to meet the desired porosity, interconnectivity, mechanical strength, bioactivity, and degradability. Hence, strontium (Sr), which is used for the treatment of osteoporosis due to its antiresorptive and anabolic effects, can be incorporated into scaffolds for better bone tissue engineering [85-87]. Sr can be incorporated into bone by two mechanisms: (a) surface exchange involving the incorporation of $\mathrm{Sr}$ into the crystal lattice of the bone mineral and (b) ionic substitution whereby $\mathrm{Sr}$ is taken up by ionic exchange with $\mathrm{Ca}$ in bone. Another benefit in using $\mathrm{Sr}$ is that it can significantly enhance collagen and non-collagen protein synthesis facilitating pre-osteoblast differentiation and inhibition of osteoclast differentiation and function [88]. Hemopoietic cells of the monocyte/macrophage lineage may differentiate into multinucleated osteoclasts cells (which are responsible for bone resorp- 
tion) under control of the bone micro- and nano-environment. Vacuolar $\mathrm{H}^{+}$-ATPase in the ruffled border membrane of osteoclasts helps to acidify the bone resorbing area. Osteoclasts attach to the bone surface in a clear zone surrounding the ruffled border facilitating bone resorption. Hence, inhibition of osteoclast differentiation is critical to control osteogenesis and restrict bone destruction [89].

Zreiqat et al. (2010) fabricated novel calcium-silicon system-based scaffolds through the controlled substitution and incorporation of strontium and zinc resulting in SrHardystonite $\left(\mathrm{Sr}-\mathrm{Ca}_{2} \mathrm{ZnSi}_{2} \mathrm{O}_{7}, \mathrm{Sr}-\mathrm{HT}\right)$ [90]. The interconnected porous network (interconnectivity: $99 \%)$, large pore size $(300-500 \mu \mathrm{m})$, and overall porosity of $78 \%$ were evident in the Sr-HT scaffolds. A remarkable induction of the attachment and differentiation of human bone derived cells (HOB) was achieved upon treatment with the Sr-HT ceramic scaffolds, which was attributed to the enhanced expression of alkaline phosphatase, Runx-2, osteopontin, osteocalcin and bone sialoprotein. Further, rapid new bone formation into the porous 3D scaffolds was reported when the Sr-HT scaffolds were implanted into tibial bone defects in rats.

In another study, Xin et al. (2009) used titanium osteoporotic bone implants as a Sr delivery platform [91]. Initially, titania nanotube arrays $\left(\mathrm{TiO}_{2}-\mathrm{NT}\right)$ were synthesized employing anodization of a chemically polished titanium plate, which were then subsequently subjected to a hydrothermal treatment in a $\mathrm{Sr}(\mathrm{OH})_{2}$ solution. This eventually resulted in well-ordered $\mathrm{SrTiO}_{3}$ nanotube arrays (Sr-NT) with a diameter of about $70 \mathrm{~nm}$ and length of about $1.3 \mu \mathrm{m}$. The $\mathrm{SrTiO}_{3}$ nanotube arrays with superior biocompatibility could support cellular adhesion, proliferation and osteogenesis providing evidence that they can be ideal candidates as improved bone implants.

\section{Titanium}

Another important metal for triggering bone tissue regeneration and support is titanium. The large surface area and highly porous nature of nanostructured titanium and its alloys have made them ideal bone substitutes. Titanium based nanostructures are mostly hydrophobic and inert. Various strategies are being developed for the surface treatment of titanium-based nanocomposites to make them ideal surfaces for enhanced cell adherence and proliferation [92-94].

For example, Yavari et al. (2014) fabricated porous titanium alloy structures from a spherical pre-alloyed Ti6Al4V ELI powder using a selective laser melting technique [95]. The resulting nanostructures were further surface modified using two different techniques, namely alkali-acid-heat treated $(\mathrm{AlAcH})$, acid-alkali $(\mathrm{AcAl})$ and anodizing-heat treated $(\mathrm{AnH})$. The porosity of the surface treated titanium alloys varied between 85 and 90\%, while the mean pore and strut sizes were 575-600 mm and 160-175 mm, respectively. The diameter of the nanotubes was between 25 and $35 \mathrm{~nm}$. Elongated human periosteumderived cells (hPDC) were more homogeneously distributed and bridged the corners on AnH surfaces. The expression of Col1 and VEGF was enhanced on day seven and day one, respectively. AlAcH surfaces also showed improved expression of Runx2 (day 21), OCN (day 1), Col1 (day 21), and VEGF (day 21) as compared to AcAl surfaces. Further, AnH provided for high bone tissue regeneration and significantly better biomechanical stability in critically-sized femoral Wistar rat bone defects.

The surface topology of the titanium nanostructures can certainly play a vital role in modulating cellular responses towards osteogenesis. Zhao et al. (2012) demonstrated that micropitted/nanotubular structures of titanium can induce more prolific osteogenic differentiation [96]. Titania nanotubes (NTs) 25 and $80 \mathrm{~nm}$ in diameter were formed with an acid-etched Ti topography (AcidTi) and hierarchical hybrid micropitted/nanotubular topography. AcidTi was further anodized at 5 and $20 \mathrm{~V}$ to form hierarchical hybrid micropitted/nanotubular topographies denoted as Micro/5VNT and Micro/20VNT, respectively, to mimic the natural nanotextured bone extracellular matrix (ECM). Significantly, cell attachment and spreading, collagen secretion, ECM mineralization, and expression of osteogenesis-related genes were enhanced in the presence of the nanotubular surface. 
However, most promising, the proliferation and osteogenic differentiation of MSCs could be induced by the Micro/20VNT sample. This finding strongly rationalized that cellular responses toward bone tissue regeneration area are related to the shape and surface feature on nanotextured materials, which needs to be carefully controlled.

Compared to bare titanium nanostructures, surface functionalized titanium dioxide nanocomposites can have a better osteoinductive effect. Zhou et al. (2013) grew strontium-doped hydroxyapatite $\left(\mathrm{Ca}_{9} \mathrm{Sr}_{1}\left(\mathrm{PO}_{4}\right)_{6}(\mathrm{OH})_{2}, \mathrm{Sr}_{1}-\mathrm{HA}\right)$ nanorods with different lateral spacing (e.g., interrod spacing) values $(67.3 \pm 3.8,95.7 \pm 4.2$, and $136.8 \pm 8.7 \mathrm{~nm})$ and nanogranulates on microarc-oxidized (MAO) microporous $\mathrm{TiO}_{2}$, respectively [97]. This resulted in a nanotopography with both a nano rod-shaped 3D pattern and a nanogranulated 2D pattern. The three coatings generated by the one-step MAO method were denoted as S67, S96, and S137, which exhibited interrod spacing values of $67.3 \pm 3.8,95.7 \pm 4.2$, and $136.8 \pm 8.7 \mathrm{~nm}$, respectively, as depicted in Figure 9. It is interesting to note that the interrod spacing values were inversely proportional to the electrolyte concentrations used. The microporous walls were nanorods with an average diameter of $70 \mathrm{~nm}$. Interrod spacing in 3D patterned coatings below $96 \mathrm{~nm}$ significantly enhanced the proliferation and differentiation of hFOB1.19 cells (a human fetal osteoblast cell line). Likewise, the surface topology also regulated intracellular $\mathrm{Ca}^{2+}$ concentrations and, thereby, cellular metabolism for better osteointegration.

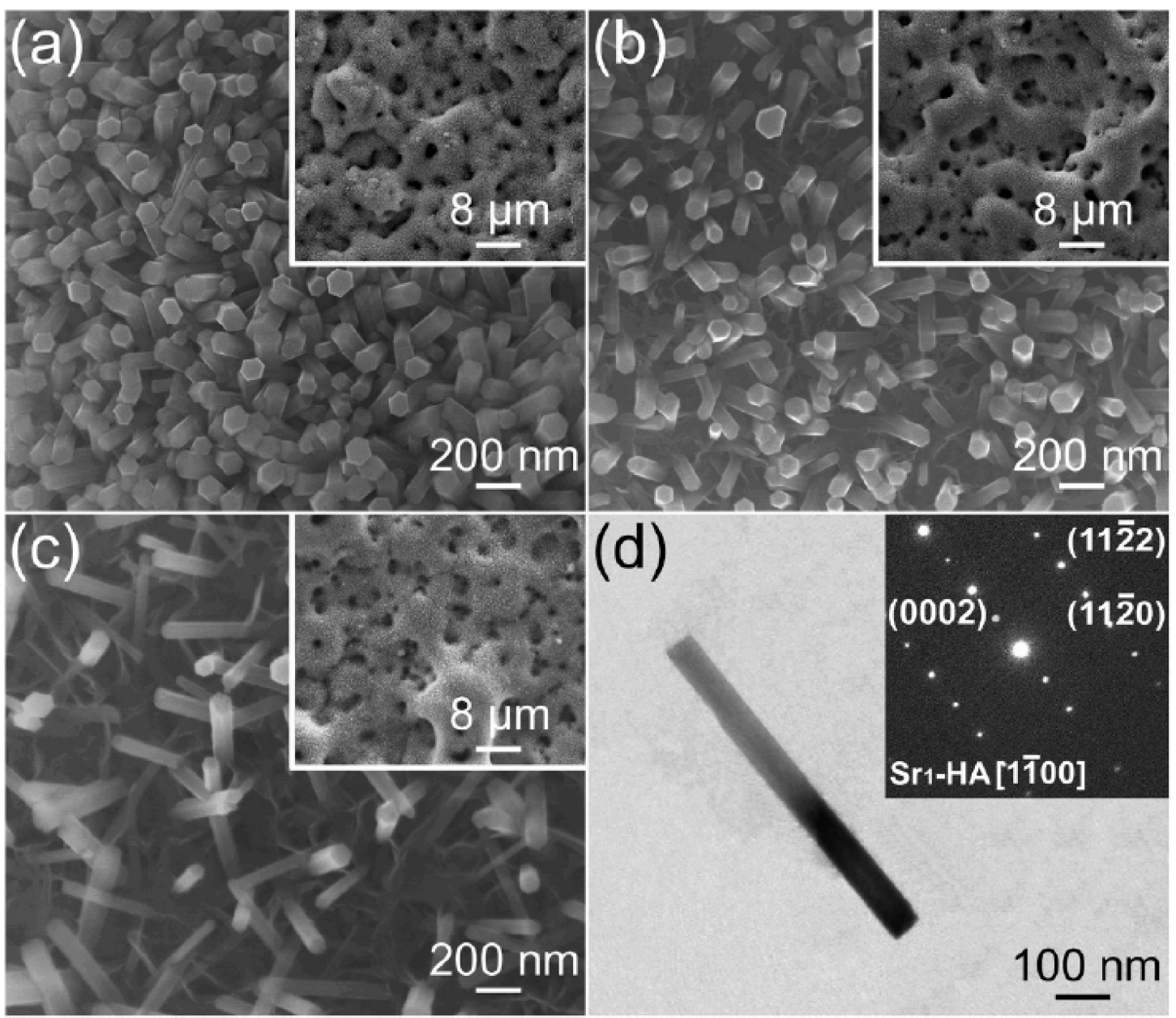

Figure 9. Scanning electron microscope (SEM) images of the surface morphologies of the microarc-oxidized (MAO) and hydrothermally treated coatings for: (a) S67, (b) S96, and (c) S137 (insets show the corresponding low-magnification images). (d) TEM bright-field image of the scratched nanorod from the S137 coating (inset showing the SAED pattern). Reproduced from [97], with permission of American Chemical Society 2013. Abbreviations: S67, nanorods with interrod spacing values of $67.3 \pm 3.8$; S96, interrod spacing values of $95.7 \pm 4.2$; and S137, interrod spacing values of $136.8 \pm 8.7 \mathrm{~nm}$. 
In an interesting study, Palin et al. (2005) established the fact that natural nanoroughness of bone itself is an important parameter that can be considered while mimicking the nanofeatures of bone [98]. Increased osteoblast adhesion and proliferation was reported when poly-lactic-co-glycolic acid (PLGA) scaffolds incorporated with nanostructured titania were used. Initially, the nanophase titania (32 nm grain size) was converted into compacts $11 \mathrm{~mm}$ in diameter associated with a PLGA model cast polymer. Interestingly, the root-mean-square surface roughness of the nanophase titania and the PLGA mold of the nanophase titania were more closely related to the natural bone surface roughness than the conventional titania. The atomic force microscopic (AFM) root-mean-square surface roughness values for the $25 \mu \mathrm{m} \times 25 \mu \mathrm{m}$ scans of cortical bovine bone, the PLGA mold of nanophase titania, and the bare nanophase titania was $25 \mathrm{~nm}, 27 \mathrm{~nm}$, and $22 \mathrm{~nm}$, respectively, which were very close to each other. On the other hand, the root-mean-square surface roughness values of conventional titania of the identical dimensions was $11 \mathrm{~nm}$ indicating its striking difference to the native bone surface topology. Hence, it is important to note that rational modulation of the nanostructured surfaces of metal nanoparticles in the scaffolds can significantly alter osteoblast adhesion and proliferation and thereby promote rapid healing of the bone defects.

\section{Zinc}

Zinc is an essential element in our body which helps in the normal functioning of several metabolic enzymes and physiological reactions. ZnONPs have been reported to ameliorate oxidative stress by scavenging harmful free radicals [99]. Also, ZnONPs can be doped with other active elements for enhanced antidiabetic activity [100]. Functionalized ZnONPs and their alloys have been reported to have potential antioxidant, antidiabetic and antibacterial activity $[101,102]$. Hence, ZnONPs are promising nanomaterials that either individually or in functionalized form, can be incorporated within scaffolds to promote bone tissue regeneration along with the prevention of reactive oxygen species (ROS) associated damage and bacterial infection mediated failure of implants. Recently, Song et al. (2020) showed the effect of zinc silicate/nanohydroxyapatite/collagen (ZS/HA/Col) scaffolds on bone regeneration and angiogenesis [103]. The 3D printed scaffolds were fabricated by using a homogeneous mixture containing nano-HA/zinc silicate powders and collagen. An increase in zinc silicate concentration enhanced the roughness of the scaffold surface and overall strength. The sustained release of zinc ions and silicon was biocompatible with BMSCs and facilitated bone regeneration in rat critical-sized bone defects. A greater mass of newly formed bone with larger volumes of calcified tissue associated with several chondrocytes were evident when defects were treated with the composite scaffolds as seen in Figure 10. Interestingly, the cartilage gradually calcified to form bone tissue, accompanied by the degradation of the scaffolds during an 8 to 12-week period. Further, the high expression of osteogenesis-related genes Bmp-2 and Osterix were associated with the in vivo bone repair process. The composite scaffolds enhanced tartrate-resistant acid phosphatase (TRAP)-positive cells, nestin-positive bone marrow stromal cells (BMSCs), and CD31-positive neovessels, angiogenesis-related (Vegf- $\alpha$ and Cd31) genes and also activated the p38 signaling pathway in monocytes. Hence, the monocytes subsequently differentiated into TRAP + cells and expressed higher levels of SDF-1, TGF- $\beta 1$, VEGF- $\alpha$, and PDGF-BB, which recruited BMSCs and endothelial cells (ECs) to the defect areas. In view of this background, ZS/HA/Col based scaffolds can be considered as promising biomaterials suitable for bone tissue engineering applications. 


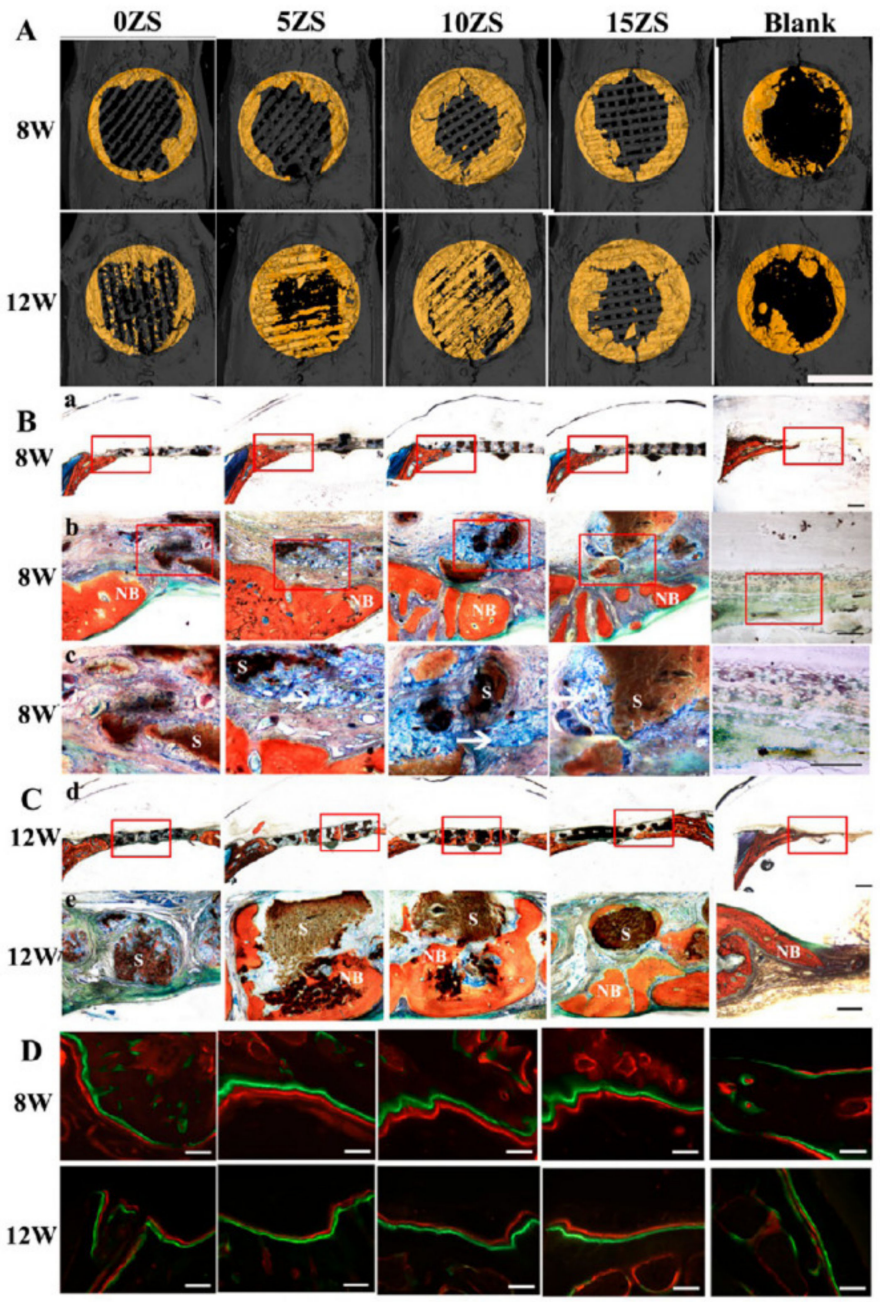

Figure 10. (A) High-resolution microcomputed tomography (Micro-CT) imaging of rat critical-sized cranial defects implanted with ZS/HA/Col scaffolds containing different proportions of zinc silicate at 8 and 12 weeks post-surgery. No scaffolds were implanted in the blank group. Newly formed bone is indicated in yellow; the scaffolds are shown in gray [scale bar: $5 \mathrm{~mm}$ ]. Histological analysis (Van Gieson staining) at 8 (B) and 12 weeks (C) after implantation [NB: neobone. S: scaffold. white arrows: cartilage. low-power images; scale bar: 2 mm (a,d). high-power images, scale bar: $200 \mu \mathrm{m}(\mathbf{b}, \mathbf{c}, \mathbf{e})]$. (D) Fluorescent double staining for alizarin red (red) and calcein (green) in the defect areas at 8 and 12 weeks after implantation [scale bar: $200 \mu \mathrm{m}$ ]. Reproduced from [103], with permission of American Chemical Society 2020. Abbreviations: 0 ZS, nano-HA/Col; 5 ZS, 5 wt\% zinc silicate/nano-HA/Col; $10 \mathrm{ZS}, 10 \mathrm{wt} \%$ zinc silicate/nano-HA/Col; $15 \mathrm{ZS}, 15 \mathrm{wt} \%$ zinc silicate/nano-HA/Col.

\section{Discussion}

Nanomedicine is a field that has already revolutionized medicine, but it continues to garner interest from materials scientists, biochemical engineers, and biologists (to just name a few) suggesting the longevity of this field. The interdisciplinary nature of nanomedicine has enabled it to expand at a very rapid pace over the past few decades to where it is now finally being applied to develop improved regenerative medicine scaffolds. Still, it is in a latent phase where several nanoparticles are being used to deliver drugs and biomolecules to the site of injury for rapid healing. However, more recently, instead of bare nanoparticles, scaffolds are being developed where a compatible and durable polymeric matrix is impregnated with various nanoparticles that are functionalized with drugs, precursors, or biomolecules such as growth factors or immunomodulatory agents.

Although various nanomaterials have been developed for several bone tissue engineering applications, their features should be closely tuned so that they can mimic the tissue 
micro- and nano-structure for the rapid attachment, proliferation, and differentiation of precursor MSCs facilitating osteogenic induction. Hereby, biomaterials should be modified into "biomimetic" nanostructures by a rational selection of the matrix, nanoparticles, or both. Type I collagen with more than 40 cellular binding sites can be used as a base material for the fabrication of scaffolds. Moreover, the scaffolds should be selectively functionalized with bone morphogenic proteins (BMPs) and proteins such as bone sialoprotein, osteocalcin, osteonectin, and matrix $\gamma$-carboxyglutamic acid (GLA) [104]. These biologically active minor components not only directly help in mineralization and integration of crystals in the collagen matrix, but also provide strong osteogenic signals to adjacent stimulating adult MSCs to differentiate into osteoblasts [105]. Further, functionalization with vascular endothelial growth factor (VEGF) can promote neovascularization in the wound site, and thereby accelerate healing. Designing scaffolds to incorporate blood vessels and nerves remain novel areas in orthopedic tissue engineering. Despite significant advancements in the field of bone tissue engineering, complete healing of traumatic bone defects remains a challenge (probably due to lack of attention to restore blood vessel and nerve networks within or next to bone implant materials). It should be noted that nerves enter bone alongside the arteries and remain closely associated with blood vessels inside bone, sharing common genetic pathways and stimuli. Thus, engineering innervated bone biomaterials for improved skeletal tissue regeneration would certainly avoid delayed or impaired recovery of bone fractures. Bone regulating neuropeptides such as calcitonin gene-related peptide (CGRP), vasoactive intestinal polypeptide(VIP), substance $\mathrm{P}(\mathrm{SP})$, and catecholamine can be functionalized on the nanotextured surface of the scaffolds to promote neurovascularized networks [106]. This innovative strategy can mimic native skeletal tissue in terms of stiffness, roughness and porosity more accurately, thus, improving the regeneration of bone tissue. Advanced technologies, such as 3D or 4D bioprinting (in which the fourth dimension is time control of implanted biomaterials), can be employed to create micro- and nano-patterned scaffold surfaces as the consequence of pits and grooves which critically control cell shape, proliferation rate, motility, differentiation, and also extra-cellular matrix production [107].

It is intriguing to ponder why in spite of their robust nature and high mechanical strength, metal nanoparticles can mimic the bone tissue microenvironment which in turn affects the adhesion and proliferation of osteoblasts, promoting the rapid healing of bone related defects. Mimicking the nanofeatures and surface roughness of the natural bone is critical when fabricating nanophase metals. This strategy would enhance osteoblast function on the scaffold surface ultimately increasing calcium deposits and bone density. Hereby, instead of using conventional metal or metal oxide nanoparticles, careful modification of the surface properties in terms of roughness and crystallinity of the nanomaterials can substantially improve orthopedic implant functionality [98].

Targeted drug delivery and triggered drug release are additional important parameters for bone tissue engineering for facilitating rapid wound healing. Surface modification of scaffolds is crucial for loading of drugs and bioactive agents such as growth factors. Several techniques such as plasma treatment, UV irradiation, chemical treatment, surface graft polymerization, and co-electrospinning of active agents and polymers can be employed either individually or in combination [108]. This might result in the generation and exposure of functional groups, such as primary amine and carboxyl groups on the scaffold surface, that can be consequently functionalized with the preferred drugs. Efficient targeted specific drug delivery can be achieved by programming stimuli responsive release systems. The conjugation of drugs on the scaffolds should be coupled with the selection of appropriate metal nanoparticles such that they can respond to a variety of stimuli such as $\mathrm{pH}$, temperature, ultrasonic waves, magnetic fields, and light for triggering the release of the drugs even on-demand and only when needed $[8,109]$. This strategy will ensure sustained drug release, prevent unwanted circulation of drugs which dilute their active conventional at the site of need, inhibit premature drug degradation, and reduce non-specific side effects of drugs. 
There are several limitations that make nanometals challenging for incorporation in scaffolds for bone tissue regeneration. The metals can leach out causing local toxicity and allergic reactions. Hereby, resorbable biomaterials are preferred as bone graft substitutes so that they can be replaced by mature bone without a transient loss of mechanical support. Since there is presently no material that can satisfy these conditions (for example, even $\mathrm{MgO}$ which is biodegradable suffers from toxic degradation by-products), non-resorbable metals such as stainless steel or titanium plates are frequently used to fix mechanically unstable bone defects. Hence, it is necessary to design scaffolds using resorbable nanostructures that can provide suitable mechanical strength, efficient bone replacement, and not release toxic degradation products [110-112].

Nanostructured ceramics (such as dicalcium phosphate, octacalcium phosphate, $\beta$ tricalcium phosphate, biphasic calcium phosphate, precipitated hydroxyapatite crystals, and $\beta$-calcium pyrophosphate) can ideally be incorporated into the scaffold matrix to make the biomaterial more resorbable due to cellular metabolism [113]. Likewise, the use of cellulose, hyaluronan, fibrin, collagen, and chitosan can make the scaffolds more resorbable as certain enzymes in the body can effectively degrade them [88].

Another limitation of metal nanoparticles includes their toxicity as various toxic chemicals are used during their synthesis and capping processes. Hence, more biocompatible nanoparticles should be incorporated into the scaffolds so that no toxicity is imposed on the organs in case the nanoparticles leach out of the scaffold surface. Biogenic nanoparticles synthesized using bacteria, fungi, algae, and medicinal plants can be used instead of chemically synthesized nanoparticles. Biogenic CuNPs, AuNPs, AgNPs, PtNPs, PdNPs, ZnONPs and their alloys can provide mechanical strength, resistance to microbial biofouling, and enhanced biocompatibility [114].

Fourth generation biomaterials that can exploit the role of bioelectricity in biological systems have a promising future in numerous biomedical applications if used for fabricating osteogenic scaffolds. These novel electrically-active materials could manipulate cellular bioelectric signals for tissue regeneration monitoring cellular responses and allow for communication with host tissues using bioelectric signals [115]. Electroactive biomaterials such as conductive polymers, piezoelectric materials, and carbon-based materials may serve as excellent components for scaffolds for more efficient electrical stimuli generation. Conductive polymers, such as poly(pyrrole) (PPy), may also ideally enhance bone formation due to electrical stimulation. Additionally, the piezoelectricity of bone-generated electrical fields, which are mainly attributed to aggregated charged ions and macromolecules in the bone interstitial fluid, can direct tissue-engineering scaffolds to enhance osteogenesis. Likewise, carbon-based materials, such as graphene, may also be used in scaffolds for electrical stimulation mediated tissue engineering. Of course, a dream for the use of electrically-active materials in bone tissue engineering scaffolds is to someday incorporate real time sensing of implant function and on-demand response to ensure implant success.

\section{Conclusions}

In this comprehensive review, we have described several metallic nanostructures that have been successfully used to fabricate scaffolds for improved bone tissue engineering. These composite nano-scaffolds can induce osteogenesis, promote mineralization, facilitate osseointegration, and also resist pathogenic biofilm mediated biofouling of implants. Further developments aim to tune the material, geometry, and architecture of these metal scaffolds so that they can mimic the tissue micro-environment, facilitate cell adhesion, proliferation, and differentiation, ensuring rapid healing of the fractures or bone defects. It is clear through this review that the wealth of knowledge created in the area of metallic nano scaffold-based tissue engineering will aid in the development of more sophisticated diagnostic and therapeutic strategies for bone injuries and defects in the decades to come.

Author Contributions: Conceptualization, T.J.W. and S.G.; resources, S.G.; data curation, S.G.; writing-original draft preparation, T.J.W. and S.G. All authors have read and agreed to the published version of the manuscript. 
Funding: This research received no external funding.

Institutional Review Board Statement: Not applicable.

Informed Consent Statement: Not applicable.

Data Availability Statement: Not applicable.

Conflicts of Interest: The authors declare no conflict of interest.

\section{Appendix A}

Table A1. Metal based nanoscaffolds for bone tissue engineering.

\begin{tabular}{|c|c|c|c|c|c|}
\hline Nanoparticles & Size (nm) & Matrix & $\begin{array}{c}\text { Functionalized } \\
\text { Ligand }\end{array}$ & Cells & Reference \\
\hline Copper nanoparticles & - & Chitosan & - & Rat calvarial defect & [39] \\
\hline $\begin{array}{l}\text { Graphene oxide-copper } \\
\text { nanocomposites }\end{array}$ & $30 \mathrm{~nm}$ & Porous calcium phosphate & - & $\begin{array}{c}\text { Rat bone marrow stem } \\
\text { cells (BMSCs) }\end{array}$ & {$[40]$} \\
\hline Copper ion & - & Mesoporous bioactive glasses & - & - & {$[42]$} \\
\hline Gold nanoparticles & $80-110 \mathrm{~nm}$ & $\begin{array}{c}\text { Mesoporous silica } \\
\text { nanoparticles, chitosan }\end{array}$ & - & $\begin{array}{l}\text { Preosteoblastic MC3T3 } \\
\text { cells, critical-sized cranial } \\
\text { defect site in rats }\end{array}$ & {$[46]$} \\
\hline Gold nanoparticles & $10.76 \pm 1.4 \mathrm{~nm}$ & - & - & $\begin{array}{l}\text { MG63 osteoblast-like } \\
\text { cells (human osteogenic } \\
\text { sarcoma) }\end{array}$ & {$[47]$} \\
\hline Gold nanoparticles & $20 \mathrm{~nm}$ & - & - & $\begin{array}{l}\text { MSCs from Kunming } \\
\text { mice }\end{array}$ & {$[48]$} \\
\hline Gold nanoparticles & $5-45 \mathrm{~nm}$ & - & - & $\begin{array}{l}\text { Human periodontal } \\
\text { ligament progenitor cells } \\
\text { (PDLPs) }\end{array}$ & {$[49]$} \\
\hline Ferrofluid & 200 & Collagen & Hydroxyapatite & $\begin{array}{l}\text { MSC from human bone } \\
\text { marrow (hBMSC) }\end{array}$ & {$[54]$} \\
\hline Iron oxide nanofiber & $600-1000$ & Poly(L-lactide) & - & MC3T3-E1 & {$[55]$} \\
\hline Fe powder & - & Hydroxypropylmethylcellulose & Hydroxyapatite & $\begin{array}{c}\text { Rabbit bone } \\
\text { marrowmesenchymal } \\
\text { stem cells (rBMSCs) }\end{array}$ & {$[58]$} \\
\hline $\begin{array}{c}\text { Superparamagnetic } \\
\text { iron oxide } \\
\text { nanoparticles }\end{array}$ & $160 \mu \mathrm{m}$ to $200 \mu \mathrm{m}$ & Poly-lactic-co-glycolic acid & - & $\begin{array}{l}\text { Murine bone BMSCs, rat } \\
\text { femoral bone }\end{array}$ & {$[59]$} \\
\hline $\begin{array}{c}\text { Iron oxide } \\
\text { nanoparticles }\end{array}$ & 7 & $\begin{array}{l}\text { Polyglucose-sorbitol- } \\
\text { carboxymethyether }\end{array}$ & - & $\begin{array}{l}\text { MSC from human bone } \\
\text { marrow (hBMSC) }\end{array}$ & {$[60]$} \\
\hline Magnetic nanoparticles & - & Polycaprolactone & - & $\begin{array}{c}\text { Mouse calvarial } \\
\text { osteoblasts }\end{array}$ & {$[61]$} \\
\hline Platinum nanoparticles & - & $\begin{array}{l}\text { Calcium phosphate, poly } \\
\text { vinyl alcohol }\end{array}$ & - & Human osteoblast cells & {$[65]$} \\
\hline Platinum nanoparticles & $10-20 \mathrm{~nm}$ & Chitosan, poly (lactic acid) & Nanohydroxyapatite & $\begin{array}{l}\text { Human osteosarcoma cell } \\
\text { line MG-63 cells }\end{array}$ & {$[66]$} \\
\hline $\begin{array}{c}\text { Palladium } \\
\text { nanoparticles }\end{array}$ & $2-5 \mathrm{~nm}$ & Reduced graphene oxide & Polypyrrole (PPy) & $\begin{array}{c}\text { Osteosarcoma osteogenic } \\
\text { cell line- } \\
\text { ATCC HTB-85 (Saos-2) }\end{array}$ & {$[67]$} \\
\hline $\begin{array}{c}\text { Palladium } \\
\text { nanoparticles, gold } \\
\text { nanorods, maghemite } \\
\text { nanoparticles }\end{array}$ & $\begin{array}{c}15 \pm 5 \mathrm{~nm}, \\
3.4 \pm 1 \mathrm{~nm} \text { and } \\
10 \mathrm{~nm}\end{array}$ & Type I collagen & $\begin{array}{c}\text { Mg doped } \\
\text { hydroxyapatite }\end{array}$ & $\begin{array}{c}\text { Adipose-derived } \\
\text { mesenchymal stem cells } \\
\text { (hADSCs) }\end{array}$ & {$[68]$} \\
\hline $\begin{array}{l}\text { Palladium } \\
\text { nanoparticles }\end{array}$ & $10 \mathrm{~nm}$ & Chitosan & $\begin{array}{c}\text { Zinc oxide } \\
\text { nanoparticles } \\
\text { impregnated } \\
\text { hydroxyapatite }\end{array}$ & $\begin{array}{l}\text { Human dental pulp stem } \\
\text { cells (hDPSCs) }\end{array}$ & {$[69]$} \\
\hline
\end{tabular}


Table A1. Cont.

\begin{tabular}{|c|c|c|c|c|c|}
\hline Nanoparticles & Size (nm) & Matrix & $\begin{array}{c}\text { Functionalized } \\
\text { Ligand }\end{array}$ & Cells & Reference \\
\hline Silver nanoparticles & $10-20 \mathrm{~nm}$ & Natural rubber latex & - & $\begin{array}{l}\text { Mesenchymal stem cells } \\
\text { of human deciduous } \\
\text { dental pulp, bone defects } \\
\text { in rat calvaria }\end{array}$ & [82] \\
\hline $\begin{array}{l}\text { Silver and gold } \\
\text { nanoparticles }\end{array}$ & $\begin{array}{c}12.7 \text { to } 69.1 \mathrm{~nm}, 9.3 \\
\text { to } 54.7 \mathrm{~nm}\end{array}$ & Silk fibroin & Hydroxyapatite & $\begin{array}{l}\text { Osteoblast-like cells } \\
\text { (MG63 } \\
\text { cell line) }\end{array}$ & [83] \\
\hline Silver nanoparticles & $5-15 \mathrm{~nm}$ & - & Collagen & $\begin{array}{l}\text { Mouse mesenchymal } \\
\text { stem cells (mMSC), } \\
\text { mouse femoral fracture } \\
\text { model }\end{array}$ & \\
\hline Strontium and zinc & & Ca-Si ceramic & & $\begin{array}{l}\text { Human bone derived } \\
\text { cells (HOB), tibial bone } \\
\text { defects in rats }\end{array}$ & {$[90]$} \\
\hline Strontium & $70 \mathrm{~nm} \times 1.3 \mu \mathrm{m}$ & Titania nanotube arrays & Hydroxyapatite & Saos- 2 cells & [91] \\
\hline Titanium & 25 to 35 & - & - & $\begin{array}{c}\text { Human } \\
\text { periosteum-derived cells } \\
\text { (hPDC), critical-size } \\
\text { femoral bone defects in } \\
\text { Wistar rats }\end{array}$ & {$[95]$} \\
\hline Titania nanotubes & $\begin{array}{l}25 \text { and } 80 \mathrm{~nm} \\
\text { (diameter), 5-10, } \\
\text { 10-20 (width) }\end{array}$ & & & $\begin{array}{l}\text { Mesenchymal stem cells } \\
\text { derived from the bone } \\
\text { marrow of Sprague } \\
\text { Dawley rats }\end{array}$ & {$[96]$} \\
\hline Titania & $3-4 \mu \mathrm{m}$ (diameter) & - & $\begin{array}{l}\text { Strontium-doped } \\
\text { hydroxyapatite }\end{array}$ & $\begin{array}{l}\text { hFOB1.19 cells (human } \\
\text { fetal osteoblast cell line) }\end{array}$ & [97] \\
\hline Titania & $32 \mathrm{~nm}$ & Poly-lactic-co-glycolic acid & - & Human osteoblast & [98] \\
\hline Zinc silicate & - & Collagen & Nano hydroxyapatite & $\begin{array}{c}\text { Rat BMSCs, monocytes, } \\
\text { andaortic endothelial } \\
\text { cells, rat critical-sized } \\
\text { cranial defects }\end{array}$ & {$[103]$} \\
\hline
\end{tabular}

\section{References}

1. Cheng, H.; Chawla, A.; Yang, Y.; Li, Y.; Zhang, J.; Jang, H.L.; Khademhosseini, A. Development of nanomaterials for bone-targeted drug delivery. Drug Discov. Today 2017, 22, 1336-1350. [CrossRef]

2. Jiang, W.; Kim, B.Y.S.; Rutka, J.T.; Chan, W.C.W. Nanoparticle-mediated cellular response is size-dependent. Nat. Nanotechnol. 2008, 3, 145-150. [CrossRef]

3. Hubbell, J.A.; Chilkoti, A. Nanomaterials for drug delivery. Science 2012, 337, 303-305. [CrossRef]

4. Hickey, D.J.; Ercan, B.; Sun, L.; Webster, T.J. Adding MgO nanoparticles to hydroxyapatite-PLLA nanocomposites for improved bone tissue engineering applications. Acta Biomater. 2015, 14, 175-184. [CrossRef]

5. Kitture, R.; Ghosh, S. Hybrid nanostructures for in-vivo imaging. In Hybrid Nanostructures for Cancer Theranostics; Bohara, R.A., Thorat, N., Eds.; Elsevier Inc.: Amsterdam, The Netherlands, 2019; pp. 173-208.

6. Liu, H.; Slamovich, E.B.; Webster, T.J. Less harmful acidic degradation of poly(lacticco-glycolic acid) bone tissue engineering scaffolds through titania nanoparticle addition. Int. J. Nanomedicine 2006, 1, 541-545. [CrossRef]

7. Ghosh, S. Mesoporous silica based nano drug delivery system synthesis, characterization and applications. In Nanocarriers for Drug Delivery; Mohapatra, S.S., Ranjan, S., Dasgupta, N., Mishra, R.K., Thomas, S., Eds.; Elsevier Inc.: Amsterdam, The Netherlands, 2019; pp. 285-317.

8. Ghosh, S.; Patil, P.D.; Kitture, R.D. Physically responsive nanostructures in breast cancer theranostics. In External Field and Radiation Stimulated Breast Cancer Nanotheranostics; Thorat, N.D., Bauer, J., Eds.; IOP Publishing Ltd.: Bristol, UK, 2019; pp. 2-1-2-24.

9. Ma, X.; Gong, N.; Zhong, L.; Sun, J.; Liang, X.-J. Future of nanotherapeutics: Targeting the cellular sub-organelles. Biomaterials 2016, 97, 10-21. [CrossRef] [PubMed]

10. Lee, D.E.; Koo, H.; Sun, I.-C.; Hee Ryu, J.H.; Kim, K.; Kwon, I.C. Multifunctional nanoparticles for multimodal imaging and theragnosis. Chem. Soc. Rev. 2012, 41, 2656-2672. [CrossRef] [PubMed]

11. Stocco, T.D.; Bassous, N.J.; Zhao, S.; Granato, A.E.C.; Webster, T.J.; Lobo, A.O. Nanofibrous scaffolds for biomedical applications. Nanoscale 2018, 10, 12228-12255. [CrossRef] [PubMed] 
12. Bassous, N.J.; Jones, C.L.; Webster, T.J. 3-D printed Ti-6Al-4V scaffolds for supporting osteoblast and restricting bacterial functions without using drugs: Predictive equations and experiments. Acta Biomater. 2019, 96, 662-673. [CrossRef]

13. Jahangirian, H.; Azizi, S.; Rafiee-Moghaddam, R.; Baratvand, B.; Webster, T.J. Status of plant protein-based green scaffolds for regenerative medicine applications. Biomolecules 2019, 9, 619. [CrossRef]

14. Rodrigues, I.C.P.; Woigt, L.F.; Pereira, K.D.; Luchessi, A.D.; Lopes, E.S.N.; Webster, T.J.; Gabriel, L.P. Low-cost hybrid scaffolds based on polyurethane and gelatine. J. Mater. Res. Technol. 2020, 9, 7777-7785. [CrossRef]

15. Rodrigues, I.C.P.; Pereira, K.D.; Woigt, L.F.; Jardini, A.L.; Luchessi, A.D.; Lopes, E.S.N.; Webster, T.J.; Gabriel, L.P. A novel technique to produce tubular scaffolds based on collagen and elastin. Artif. Organs 2021, 45, E113-E122. [CrossRef]

16. Mostafavi, A.; Abudula, T.; Russell, C.S.; Mostafavi, E.; Williams, T.J.; Salah, N.; Alshahrie, A.; Harris, S.; Basri, S.M.M.; Mishra, Y.K.; et al. In situ printing of scaffolds for reconstruction of bone defects. Acta Biomater. 2021, 127, 313-326. [CrossRef] [PubMed]

17. Noori, A.; Ashrafi, S.J.; Vaez-Ghaemi, R.; Hatamian-Zaremi, A.; Webster, T.J. A review of fibrin and fibrin composites for bone tissue engineering. Int. J. Nanomedicine 2017, 12, 4937-4961. [CrossRef] [PubMed]

18. Zhang, L.; Rakotondradany, F.; Myles, A.J.; Fenniri, H.; Webster, T.J. Arginine-glycine-aspartic acid modified rosette nanotubehydrogel composites for bone tissue engineering. Biomaterials 2009, 30, 1309-1320. [CrossRef]

19. Brannigan, K.; Griffin, M. An update into the application of nanotechnology in bone healing. Open Orthop. J. 2016, 10, 808-823. [CrossRef] [PubMed]

20. Neogi, T.; Zhang, Y. Epidemiology of osteoarthritis. Rheum. Dis. Clin. North Am. 2013, 39, 1-19. [CrossRef]

21. Wright, N.C.; Looker, A.C.; Saag, K.G.; Curtis, J.R.; Delzell, E.S.; Randall, S.; Dawson-Hughes, B. The recent prevalence of osteoporosis and low bone mass in the United States based on bone mineral density at the femoral neck or lumbar spine. J. Bone Miner. Res. 2014, 29, 2520-2526. [CrossRef]

22. Hak, D.J.; Fitzpatrick, D.; Bishop, J.A.; Marsh, J.L.; Tilp, S.; Schnettler, R.; Simpson, H.; Alt, V. Delayed union and nonunions: Epidemiology, clinical issues, and financial aspects. Injury 2014, 45, S3-S7. [CrossRef]

23. Rajani, R.; Schaefer, L.; Scarborough, M.T.; Gibbs, C.P. Giant cell tumors of the foot and ankle bones: High recurrence rates after surgical treatment. J. Foot Ankle Surg. 2015, 54, 1141-1145. [CrossRef]

24. Nguyen, T.B.L.; Min, Y.K.; Lee, B.T. Nanoparticle biphasic calcium phosphate loading on gelatin-pectin scaffold for improved bone regeneration. Tissue Eng. Part A 2015, 21, 1376-1387. [CrossRef]

25. Xing, Z.; Pedersen, T.O.; Wu, X.; Xue, Y.; Sun, Y.; Finne-Wistrand, A.; Kloss, F.R.; Waag, T.; Krueger, A.; Steinmüller-Nethl, D.; et al. Biological effects of functionalizing copolymer scaffolds with nanodiamond particles. Tissue Eng. Part A 2013, 19, 1783-1791. [CrossRef]

26. Cross, L.M.; Thakur, A.; Jalili, N.A.; Detamore, M.; Gaharwar, A.K. Nanoengineered biomaterials for repair and regeneration of orthopedic tissue interfaces. Acta Biomater. 2016, 42, 2-17. [CrossRef] [PubMed]

27. Funda, G.; Taschieri, S.; Bruno, G.A.; Grecchi, E.; Paolo, S.; Girolamo, D.; Fabbro, M.D. Nanotechnology scaffolds for alveolar bone regeneration. Materials 2020, 13, 201. [CrossRef] [PubMed]

28. Gong, T.; Xie, J.; Liao, J.; Zhang, T.; Lin, S.; Lin, Y. Nanomaterials and bone regeneration. Bone Res. 2015, 3, 15029. [CrossRef] [PubMed]

29. Gorain, B.; Tekade, M.; Kesharwani, P.; Iyer, A.K.; Kalia, K.; Tekade, R.K. The use of nanoscaffolds and dendrimers in tissue engineering. Drug Discov. Today 2017, 22, 652-664. [CrossRef] [PubMed]

30. Tschernitschek, H.; Borchers, L.; Geurtsen, W. Nonalloyed titanium as a bioinert metal-A review. Quintessence Int. 2005, 36, 523-530. [CrossRef] [PubMed]

31. Van den Bosch, M.; Sang, Å.O. Urban natural environments as nature-based solutions for improved public health—A systematic review of reviews. Env. Res. 2017, 158, 373-384. [CrossRef] [PubMed]

32. Smith, V.; Devane, D.; Begley, C.M.; Clarke, M. Methodology in conducting a systematic review of systematic reviews of healthcare interventions. BMC Med. Res. Methodol. 2011, 11, 1-6. [CrossRef]

33. Shea, B.J.; Hamel, C.; Wells, G.A.; Bouter, L.M.; Kristjansson, E.; Grimshaw, J.; Henry, D.A.; Boers, M. AMSTAR is a reliable and valid measurement tool to assess the methodological quality of systematic reviews. J. Clin. Epidemiol. 2009, 62, 1013-1020. [CrossRef]

34. Brok, J.; Thorlund, K.; Gluud, C.; Wetterslev, J. Trial sequential analysis reveals insufficient information size and potentially false positive results in many metaanalyses. J. Clin. Epidemiol. 2008, 61, 763-769. [CrossRef] [PubMed]

35. Jamdade, D.A.; Rajpali, D.; Joshi, K.A.; Kitture, R.; Kulkarni, A.S.; Shinde, V.S.; Bellare, J.; Babiya, K.R.; Ghosh, S. Gnidia glauca and Plumbago zeylanica mediated synthesis of novel copper nanoparticles as promising antidiabetic agents. Adv. Pharmacol. Sci. 2019, 2019, 9080279. [CrossRef] [PubMed]

36. Bhagwat, T.R.; Joshi, K.A.; Parihar, V.S.; Asok, A.; Bellare, J.; Ghosh, S. Biogenic copper nanoparticles from medicinal plants as novel antidiabetic nanomedicine. World J. Pharm. Res. 2018, 7, 183-196.

37. Ghosh, S.; More, P.; Nitnavare, R.; Jagtap, S.; Chippalkatti, R.; Derle, A.; Kitture, R.; Asok, A.; Kale, S.; Singh, S.; et al. Antidiabetic and antioxidant properties of copper nanoparticles synthesized by medicinal plant Dioscorea bulbifera. J. Nanomed. Nanotechnol. 2015, S6, 007. [CrossRef]

38. Ghosh, S. Copper and palladium nanostructures: A bacteriogenic approach. Appl. Microbiol. Biotechnol. 2018, $101,7693-7701$. [CrossRef] [PubMed] 
39. D’Mello, S.; Elangovan, S.; Hong, L.; Ross, R.D.; Sumner, D.R.; Salem, A.K. Incorporation of copper into chitosan scaffolds promotes bone regeneration in rat calvarial defects. J. Biomed. Mater. Res. Part B. 2015, 103B, 1044-1049. [CrossRef]

40. Zhang, W.; Chang, Q.; Xu, L.; Li, G.; Yang, G.; Ding, X.; Wang, X.; Cui, D.; Jiang, X. Graphene oxide-copper nanocomposite-coated porous CaP scaffold for vascularized bone regeneration via activation of Hif-1 $\alpha$. Adv. Healthcare Mater. 2016, 5, 1299-1309. [CrossRef] [PubMed]

41. Wan, C.; Shao, J.; Gilbert, S.R.; Riddle, R.C.; Long, F.; Johnson, R.S.; Schipani, E.; Clemens, T.L. Role of HIF-1 $\alpha$ in skeletal development. Ann. N. Y. Acad. Sci. 2010, 1192, 322-326. [CrossRef] [PubMed]

42. Bari, A.; Bloise, N.; Fiorilli, S.; Novajra, G.; Vallet-Regí, M.; Bruni, G.; Torres-Pardo, A.; González-Calbet, J.M.; Visai, L.; Vitale-Brovarone, C. Copper-containing mesoporous bioactive glass nanoparticles as multifunctional agent for bone regeneration. Acta Biomater. 2017, 55, 493-504. [CrossRef]

43. Ghosh, S.; Patil, S.; Chopade, N.B.; Luikham, S.; Kitture, R.; Gurav, D.D.; Patil, A.B.; Phadatare, S.D.; Sontakke, V.; Kale, S.; et al. Gnidia glauca leaf and stem extract mediated synthesis of gold nanocatalysts with free radical scavenging potential. J. Nanomed. Nanotechnol. 2016, 7, 358. [CrossRef]

44. Shende, S.; Joshi, K.A.; Kulkarni, A.S.; Shinde, V.S.; Parihar, V.S.; Kitture, R.; Banerjee, K.; Kamble, N.; Bellare, J.; Ghosh, S. Litchi chinensis peel: A novel source for synthesis of gold and silver nanocatalysts. Glob. J. Nanomedicine 2017, 3, 555603.

45. Ghosh, S.; Jagtap, S.; More, P.; Shete, U.J.; Maheshwari, N.O.; Rao, S.J.; Kitture, R.; Kale, S.; Bellare, J.; Patil, S.; et al. Dioscorea bulbifera mediated synthesis of novel $\mathrm{Au}_{\text {core }} \mathrm{Ag}_{\text {shell }}$ nanoparticles with potent antibiofilm and antileishmanial activity. J. Nanomater. 2015, 2015, 562938. [CrossRef]

46. Liang, H.; Jin, C.; Ma, L.; Feng, X.; Deng, X.; Wu, S.; Liu, X.; Yang, C. Accelerated bone regeneration by gold-nanoparticle-loaded mesoporous silica through stimulating immunomodulation. ACS Appl. Mater. Interfaces 2019, 11, 41758-41769. [CrossRef]

47. Tsai, S.-W.; Liaw, J.-W.; Kao, Y.-C.; Huang, M.-Y.; Lee, C.-Y.; Rau, L.-R.; Huang, C.-Y.; Wei, K.-C.; Ye, T.-C. Internalized gold nanoparticles do not affect the osteogenesis and apoptosis of MG63 osteoblast-like cells: A quantitative, in vitro study. PLoS ONE 2013, 8, e76545. [CrossRef] [PubMed]

48. Yi, C.; Liu, D.; Fong, C.-C.; Zhang, J.; Yang, M. Gold nanoparticles promote osteogenic differentiation of mesenchymal stem cells through p38 MAPK pathway. ACS Nano 2010, 4, 6439-6448. [CrossRef] [PubMed]

49. Zhang, Y.; Kong, N.; Zhang, Y.; Yang, W.; Yan, F. Size-dependent effects of gold nanoparticles on osteogenic differentiation of human periodontal ligament progenitor cells. Theranostics 2017, 7, 1214-1224. [CrossRef]

50. Zhang, X.; Cheng, G.; Xing, X.; Liu, J.; Cheng, Y.; Ye, T.; Wang, Q.; Xiao, X.; Li, Z.; Deng, H. Near-infrared light-triggered porous AuPd alloy nanoparticles to produce mild localized heat to accelerate bone regeneration. J. Phys. Chem. Lett. 2019, 10, 4185-4191. [CrossRef]

51. Zhang, Y.; Wang, P.; Mao, H.; Zhang, Y.; Zheng, L.; Yu, P.; Guo, Z.; Li, L.; Jiang, Q. PEGylated gold nanoparticles promote osteogenic differentiation in in vitro and in vivo systems. Mater. Des. 2021, 197, 109231. [CrossRef]

52. Ghosh, S.; Sanghavi, S.; Sancheti, P. Metallic biomaterial for bone support and replacement. In Fundamental Biomaterials: Metals; Balakrishnan, P., Sreekala, M.S., Thomas, S., Eds.; Woodhead Publishing Series in Biomaterials; Woodhead Publishing: Cambridge, UK, 2018; Volume 2, pp. 139-165.

53. Ghosh, S.; More, P.; Derle, A.; Kitture, R.; Kale, T.; Gorain, M.; Avasthi, A.; Markad, P.; Kundu, G.C.; Kale, S.; et al. Diosgenin functionalized iron oxide nanoparticles as novel nanomaterial against breast cancer. J. Nanosci. Nanotechnol. 2015, 15, 9464-9472 [CrossRef] [PubMed]

54. Bock, N.; Riminucci, A.; Dionigi, C.; Russo, A.; Tampieri, A.; Landi, E.; Goranov, V.A.; Marcacci, M.; Dediu, V. A novel route in bone tissue engineering: Magnetic biomimetic scaffolds. Acta Biomater. 2010, 6, 786-796. [CrossRef]

55. Cai, Q.; Shi, Y.; Shan, D.; Jia, W.; Duan, S.; Deng, X.; Yang, X. Osteogenic differentiation of MC3T3-E1 cells on poly(L-lactide)/Fe ${ }_{3} \mathrm{O}_{4}$ nanofibers with static magnetic field exposure. Mater. Sci. Eng. C 2015, 55, 166-173. [CrossRef]

56. Rajesh, R.; Ravichandran, Y.D. Development of a new carbon nanotube-alginate-hydroxyapatite tricomponent composite scaffold for application in bone tissue engineering. Int. J. Nanomed. 2015, 10, 7-15.

57. Yang, L.; Webster, T.J. Nanotechnology controlled drug delivery for treating bone diseases. Expert Opin. Drug Deliv. 2009, 6, 851-864. [CrossRef]

58. Yang, C.; Huan, Z.; Wang, X.; Wu, C.; Chang, J. 3D printed Fe scaffolds with HA nanocoating for bone regeneration. ACS Biomater. Sci. Eng. 2018, 4, 608-616. [CrossRef]

59. Zhao, Y.-Z.; Chen, R.; Xue, P.-P.; Luo, L.-Z.; Zhong, B.; Tong, M.-Q.; Chen, B.; Yao, Q.; Yuan, J.-D.; Xu, H.-L. Magnetic PLGA microspheres loaded with SPIONs promoted the reconstruction of bone defects through regulating the bone mesenchymal stem cells under an external magnetic field. Mater. Sci. Eng. C 2021, 122, 111877. [CrossRef] [PubMed]

60. Wang, Q.; Chen, B.; Cao, M.; Sun, J.; Wu, H.; Zhao, P.; Xing, J.; Yang, Y.; Zhang, X.; Ji, M.; et al. Response of MAPK pathway to iron oxide nanoparticles in vitro treatment promotes osteogenic differentiation of hBMSCs. Biomaterials 2016, 86, 11-20. [CrossRef]

61. Yun, H.-M.; Ahn, S.-J.; Park, K.-R.; Kim, M.-J.; Kim, J.-J.; Jin, G.-Z.; Kim, H.-W.; Kim, E.-C. Magnetic nanocomposite scaffolds combined with static magnetic field in the stimulation of osteoblastic differentiation and bone formation. Biomaterials 2016, 85, 88-98. [CrossRef]

62. Rokade, S.; Joshi, K.; Mahajan, K.; Patil, S.; Tomar, G.; Dubal, D.; Parihar, V.S.; Kitture, R.; Bellare, J.R.; Ghosh, S. Gloriosa superba mediated synthesis of platinum and palladium nanoparticles for induction of apoptosis in breast cancer. Bioinorg. Chem. Appl. 2018, 2018, 4924186. [CrossRef] [PubMed] 
63. Rokade, S.S.; Joshi, K.A.; Mahajan, K.; Tomar, G.; Dubal, D.S.; Parihar, V.S.; Kitture, R.; Bellare, J.; Ghosh, S. Novel anticancer platinum and palladium nanoparticles from Barleria prionitis. Glob. J. Nanomedicine 2017, 2, 555600.

64. Ghosh, S.; Nitnavare, R.; Dewle, A.; Tomar, G.B.; Chippalkatti, R.; More, P.; Kitture, R.; Kale, S.; Bellare, J.; Chopade, B.A. Novel platinum-palladium bimetallic nanoparticles synthesized by Dioscorea bulbifera: Anticancer and antioxidant activities. Int. J. Nanomedicine. 2015, 10, 7477-7490.

65. Eid, K.; Eldesouky, A.; Fahmy, A.; Shahat, A.; Elaal, R.A. Calcium phosphate scaffold loaded with platinum nanoparticles for bone allograft. Am. J. Biomed. Sci. 2013, 5, 242-249. [CrossRef]

66. Radwan-Pragłowska, J.; Janus, Ł.; Piatkowski, M.; Bogdał, D.; Matysek, D. 3D hierarchical, nanostructured chitosan/PLA/HA scaffolds doped with $\mathrm{TiO}_{2} / \mathrm{Au} / \mathrm{Pt}$ NPs with tunable properties for guided bone tissue engineering. Polymers 2020, 12, 792. [CrossRef] [PubMed]

67. Balaji, M.; Nithya, P.; Mayakrishnan, A.; Jegatheeswaran, S.; Selvam, S.; Cai, Y.; Yao, J.; Sundrarajan, M. Fabrication of palladium nanoparticles anchored polypyrrole functionalized reduced graphene oxide nanocomposite for antibiofilm associated orthopedic tissue engineering. Appl. Surf. Sci. 2020, 510, 145403.

68. Calabrese, G.; Petralia, S.; Fabbi, C.; Forte, S.; Franco, D.; Guglielmino, S.; Esposito, E.; Cuzzocrea, S.; Traina, F.; Conoci, S. Au, Pd and maghemite nanofunctionalized hydroxyapatite scaffolds for bone regeneration. Regen. Biomater. 2020, 7, 461-469. [CrossRef] [PubMed]

69. Heidari, F.; Tabatabaei, F.S.; Razavi, M.; Lari, R.B.; Tavangar, M.; Romanos, G.E.; Vashaee, D.; Tayebi, L. 3D construct of hydroxyapatite/zinc oxide/palladium nanocomposite scaffold for bone tissue engineering. J. Mater. Sci. Mater. Med. 2020, $31,85$. [CrossRef] [PubMed]

70. Ghosh, S.; Harke, A.N.; Chacko, M.J.; Gurav, S.P.; Joshi, K.A.; Dhepe, A.; Dewle, A.; Tomar, G.B.; Kitture, R.; Parihar, V.S.; et al. Gloriosa superba mediated synthesis of silver and gold nanoparticles for anticancer applications. J. Nanomed. Nanotechnol. 2016, 7. [CrossRef]

71. Ghosh, S.; Chacko, M.J.; Harke, A.N.; Gurav, S.P.; Joshi, K.A.; Dhepe, A.; Kulkarni, A.S.; Shinde, V.S.; Parihar, V.S.; Asok, A.; et al. Barleria prionitis leaf mediated synthesis of silver and gold nanocatalysts. J. Nanomed. Nanotechnol. 2016, 7. [CrossRef]

72. Shende, S.; Joshi, K.A.; Kulkarni, A.S.; Charolkar, C.; Shinde, V.S.; Parihar, V.S.; Kitture, R.; Banerjee, K.; Kamble, N.; Bellare, J.; et al. Platanus orientalis leaf mediated rapid synthesis of catalytic gold and silver nanoparticles. J. Nanomed. Nanotechnol. 2018, 9, 2. [CrossRef]

73. Shinde, S.S.; Joshi, K.A.; Patil, S.; Singh, S.; Kitture, R.; Bellare, J.; Ghosh, S. Green synthesis of silver nanoparticles using Gnidia glauca and computational evaluation of synergistic potential with antimicrobial drugs. World J. Pharm. Res. 2018, 7, $156-171$.

74. Joshi, K.A.; Ghosh, S.; Dhepe, A. Green synthesis of antimicrobial nanosilver using in-vitro cultured Dioscorea bulbifera. Asian J. Org. Med. Chem. 2019, 4, 222-227. [CrossRef]

75. Sant, D.G.; Gujarathi, T.R.; Harne, S.R.; Ghosh, S.; Kitture, R.; Kale, S.; Chopade, B.A.; Pardesi, K.R. Adiantum philippense L. frond assisted rapid green synthesis of gold and silver nanoparticles. J. Nanoparticles 2013, 2013, 1-9. [CrossRef]

76. Salunke, G.R.; Ghosh, S.; Santosh, R.J.; Khade, S.; Vashisth, P.; Kale, T.; Chopade, S.; Pruthi, V.; Kundu, G.; Bellare, J.R.; et al. Rapid efficient synthesis and characterization of AgNPs, AuNPs and AgAuNPs from a medicinal plant, Plumbago zeylanica and their application in biofilm control. Int. J. Nanomedicine 2014, 9, 2635-2653. [PubMed]

77. Ranpariya, B.; Salunke, G.; Karmakar, S.; Babiya, K.; Sutar, S.; Kadoo, N.; Kumbhakar, P.; Ghosh, S. Antimicrobial synergy of silver-platinum nanohybrids with antibiotics. Front. Microbiol. 2021, 11, 610968. [CrossRef]

78. Cao, H.; Zhang, W.; Meng, F.; Guo, J.; Wang, D.; Qian, S.; Jiang, X.; Liu, X.; Chu, P.K. Osteogenesis catalyzed by titanium-supported silver nanoparticles. ACS Appl. Mater. Interfaces 2017, 9, 5149-5157. [CrossRef]

79. Castiglioni, S.; Cazzaniga, A.; Locatelli, L.; Maier, J.A.M. Silver nanoparticles in orthopedic applications: New insights on their effects on osteogenic cells. Nanomaterials 2017, 7, 124. [CrossRef]

80. Jiang, J.; Li, L.; Li, K.; Li, G.; You, F.; Zuo, Y.; Li, Y.; Li, J. Antibacterial nanohydroxyapatite/polyurethane composite scaffolds with silver phosphate particles for bone regeneration. J. Biomater. Sci. Polym. Ed. 2016, 27, 1584-1598. [CrossRef]

81. Jin, S.; Li, J.; Wang, J.; Jiang, J.; Zuo, Y.; Li, Y.; Yang, F. Electrospun silver ion-loaded calcium phosphate/chitosan antibacterial composite fibrous membranes for guided bone regeneration. Int. J. Nanomedicine 2018, 13, 4591-4605. [CrossRef]

82. Marques, L.; Martinez, G.; Guidelli, E.; Tamashiro, J.; Segato, R.; Payão, S.L.M.; Baa, O.; Kinoshita, A. Performance on bone regeneration of a silver nanoparticle delivery system based on natural rubber membrane NRL-AgNP. Coatings 2020, 10, 323. [CrossRef]

83. Ribeiro, M.; Ferraz, M.P.; Monteiro, F.J.; Fernandes, M.H.; Beppu, M.M.; Mantione, D.; Sardon, H. Antibacterial silk fibroin/nanohydroxyapatite hydrogels with silver and gold nanoparticles for bone regeneration. Nanomedicine 2017, 13, 231-239. [CrossRef]

84. Zhang, R.; Lee, P.; Lui, V.C.H.; Chen, Y.; Liu, X.; Lok, C.N.; To, M.; Yeung, K.W.K.; Wong, K.K.Y. Silver nanoparticles promote osteogenesis of mesenchymal stem cells and improve bone fracture healing in osteogenesis mechanism mouse model. Nanomedicine 2015, 11, 1949-1959. [CrossRef]

85. Marie, P.J. Strontium ranelate: A novel mode of action optimizing bone formation and resorption. Osteoporos. Int. 2005, 16, S7-S10. [CrossRef] [PubMed]

86. Ammann, P. Strontium ranelate: A novel mode of action leading to renewed bone quality. Osteoporos. Int. 2005, 16, S11-S15. [CrossRef] 
87. Marie, P.J. Strontium ranelate: New insights into its dual mode of action. Bone 2007, 4, S5-S8. [CrossRef]

88. Ghosh, S.; Webster, T.J. Mesoporous silica based nanostructures for bone tissue regeneration. Front. Mater. $2021,8,692309$. [CrossRef]

89. Katagiri, T.; Takahashi, N. Regulatory mechanisms of osteoblast and osteoclast differentiation. Oral Dis. 2002, 8, 147-159. [CrossRef]

90. Zreiqat, H.; Ramaswamy, Y.; Wu, C.; Paschalidis, A.; Lu, Z.; James, B.; Birke, O.; McDonald, M.; Little, D.; Dunstan, C.R. The incorporation of strontium and zinc into a calcium-silicon ceramic for bone tissue engineering. Biomaterials 2010, 31, 3175-3184. [CrossRef]

91. Xin, Y.; Jiang, J.; Huo, K.; Hu, T.; Chu, P.K. Bioactive $\mathrm{SrTiO}_{3}$ nanotube arrays: Strontium delivery platform on Ti-based osteoporotic bone implants. ACS Nano 2009, 3, 3228-3234. [CrossRef]

92. Brammer, K.S.; Oh, S.H.; Gallagher, J.O.; Jin, S.H. Enhanced cellular mobility guided by $\mathrm{TiO}_{2}$ nanotube surfaces. Nano. Lett. 2008, 8, 786-793. [CrossRef]

93. Macak, J.M.; Tsuchiya, H.; Ghicov, A.; Yasuda, K.; Hahn, R.; Bauer, S.; Schmuki, P. $\mathrm{TiO}_{2}$ nanotubes: Self-organized electrochemical formation, properties and applications. Curr. Opin. Solid State Mater. Sci. 2007, 11, 3-18. [CrossRef]

94. Ghicov, A.; Schmuki, P. Self-ordering electrochemistry: A review on growth and functionality of $\mathrm{TiO}_{2}$ nanotubes and other self-aligned MOx structures. Chem. Commun. 2009, 2791-2808. [CrossRef] [PubMed]

95. Yavari, S.A.; van der Stok, J.; Chai, Y.C.; Wauthle, R.; Birgani, Z.T.; Habibovic, P.; Mulier, M.; Schrooten, J.; Weinans, H.; Zadpoor, A.A. Bone regeneration performance of surface-treated porous titanium. Biomaterials 2014, 35, 6172-6181. [CrossRef]

96. Zhao, L.; Liu, 1.; Wu, Z.; Zhang, y.; Chu, P.K. Effects of micropitted/nanotubular titania topographies on bone mesenchymal stem cell osteogenic differentiation. Biomaterials 2012, 33, 2629-2641. [CrossRef]

97. Zhou, J.; Li, B.; Lu, S.; Zhang, L.; Han, Y. Regulation of osteoblast proliferation and differentiation by interrod spacing of Sr-HA nanorods on microporous titania coatings. ACS Appl. Mater. Interfaces 2013, 5, 5358-5365. [CrossRef]

98. Palin, E.; Liu, H.; Webster, T.J. Mimicking the nanofeatures of bone increases bone-forming cell adhesion and proliferation. Nanotechnology 2005, 16, 1828-1835. [CrossRef]

99. Adersh, A.; Kulkarni, A.R.; Ghosh, S.; More, P.; Chopade, B.A.; Gandhi, M.N. Surface defect rich ZnO quantum dots as antioxidant inhibiting $\alpha$-amylase and $\alpha$-glucosidase: A potential anti-diabetic nanomedicine. J. Mater. Chem. B. 2015, 3, 4597-4606.

100. Robkhob, P.; Ghosh, S.; Bellare, J.; Jamdade, D.; Tang, I.M.; Thongmee, S. Effect of silver doping on antidiabetic and antioxidant potential of ZnO nanorods. J. Trace Elem. Med. Biol. 2020, 58, 126448. [CrossRef] [PubMed]

101. Kitture, R.; Chordiya, K.; Gaware, S.; Ghosh, S.; More, P.A.; Kulkarni, P.; Chopade, B.A.; Kale, S.N. ZnO nanoparticles-red sandalwood conjugate: A promising anti-diabetic agent. J. Nanosci. Nanotechnol. 2015, 15, 4046-4051. [CrossRef]

102. Karmakar, S.; Ghosh, S.; Kumbhakar, P. Enhanced sunlight driven photocatalytic and antibacterial activity of flower-like $\mathrm{ZnO@MoS} 2$ nanocomposite. J. Nanopart. Res. 2020, 22, 11. [CrossRef]

103. Song, Y.; Wu, H.; Gao, Y.; Li, J.; Lin, K.; Liu, B.; Lei, X.; Cheng, P.; Zhang, S.; Wang, Y.; et al. Zinc silicate/nanohydroxyapatite/collagen scaffolds promote angiogenesis and bone regeneration via the p38 MAPK pathway in activated monocytes. ACS Appl. Mater. Interfaces 2020, 12, 16058-16075. [CrossRef] [PubMed]

104. Mehta, M.; Schmidt-Bleek, K.; Duda, G.N.; Mooney, D.J. Biomaterial delivery of morphogens to mimic the natural healing cascade in bone. Adv. Drug Deliv. Rev. 2012, 64, 1257-1276. [CrossRef] [PubMed]

105. Kane, R.; Ma, P.X. Mimicking the nanostructure of bone matrix to regenerate bone. Mater. Today 2013, 16, 418-423. [CrossRef]

106. Marrella, A.; Lee, T.Y.; Lee, D.H.; Karuthedom, S.; Syla, D.; Chawla, A.; Khademhosseini, A.; Jang, H.L. Engineering vascularized and innervated bone biomaterials for improved skeletal tissue regeneration. Mater. Today 2018, 21, 362-376. [CrossRef] [PubMed]

107. Ghosh, S.; Mostafavi, E.; Thorat, N.; Webster, T.J. Nanobiomaterials for three-dimensional bioprinting. In Nanotechnology in Medicine and Biology; Liu, H., Shokuhfar, T., Ghosh, S., Eds.; Elsevier: Amsterdam, The Netherlands, 2021. (In press)

108. Monteiro, N.; Martins, A.; Reis, R.L.; Neves, N.M. Nanoparticle-based bioactive agent release systems for bone and cartilage tissue engineering. Regen. Ther. 2015, 1, 109-118. [CrossRef]

109. Vo, T.N.; Kasper, F.K.; Mikos, A.G. Strategies for controlled delivery of growth factors and cells for bone regeneration. Adv. Drug Deliv. Rev. 2012, 64, 1292-1309. [CrossRef] [PubMed]

110. Gogolewski, S.; Jovanovic, M.; Perren, S.M.; Dillon, J.G.; Hughes, M.K. Tissue response and in vivo degradation of selected polyhydroxyacids: Polylactides (PLA), poly(3-hydroxybutyrate) (PHB), and poly(3-hydroxybutyrate-co-3-hydroxyvalerate) (PHB/VA). J. Biomed. Mater. Res. 1993, 27, 1135-1148. [CrossRef] [PubMed]

111. Freiberg, S.; Zhu, X.X. Polymer microspheres for controlled drug release. Int. J. Pharm. 2004, 282, 1-18. [CrossRef] [PubMed]

112. Witte, F.; Fischer, J.; Nellesen, J.; Crostack, H.A.; Kaese, V.; Pisch, A.; Beckmann, F.; Windhagen, H. In vitro and in vivo corrosion measurements of magnesium alloys. Biomaterials 2006, 27, 1013-1018. [CrossRef]

113. Bohner, M. Resorbable biomaterials as bone graft substitutes. Mater. Today 2010, 13, 24-30. [CrossRef]

114. Ghosh, S.; Webster, T.J. Nanobiotechnology: Microbes and Plant Assisted Aynthesis of Nanoparticles, Mechanisms and Applications; Elsevier Inc.: Amsterdam, The Netherlands, 2021.

115. Ning, C.; Zhou, L.; Tan, G. Fourth-generation biomedical materials. Mater. Today 2016, 19, 1-3. [CrossRef] 